\title{
Análise das Propriedades Físicas e Químicas da Dentina De Dentes Decíduos e Permanentes - Estudo In Vitro
}

Tese apresentada à Faculdade de Odontologia de Ribeirão Preto da Universidade de São Paulo para obtenção do título de Doutor em Ciências.

Programa: Odontopediatria

Área de Concentração: Odontopediatria

Orientador: Profa. Dra. Maria CRISTINA BorSATto Coorientador: Profa. Dra. Regina GuenKa Palma DibB

Ribeirão Preto - SP 


\section{AUTORIZAÇÃo PARA REPRODUÇÃo}

Autorizo a reprodução e/ou divulgação total ou parcial da presente obra, por qualquer meio convencional ou eletrônico, desde que citada a fonte.

Ficha Catalográfica

Torres-Mantovani, Carolina Paes

Análise das propriedades físicas e químicas da dentina de dentes decíduos e permanentes - Estudo in vitro. Ribeirão Preto, 2011.

76 p. : il. ; $30 \mathrm{~cm}$

Tese de Doutorado, apresentada à Faculdade de Odontologia de Ribeirão Preto/USP - Área de Concentração: Odontopediatria.

Orientador: Borsatto, Maria Cristina

Coorientador: Palma-Dibb, Regina Guenka

1. Dentina 2. Dentes decíduos 3. Dentes permanentes 4. Propriedades químicas

5. Propriedades físicas 
FOLHA DE APROVAÇÃO

Torres-Mantovani CP. Análise das propriedades físicas e químicas da dentina de dentes decíduos e permanentes - estudo in vitro. Tese apresentada à Faculdade de Odontologia de Ribeirão Preto da Universidade de São Paulo, para obtenção do Título de Doutor em Ciências. Área de Concentração: Odontopediatria.

Data da defesa:

\section{BANCA EXAMINADORA}

Prof. Dr.

Julgamento Assinatura

Prof. Dr.

Julgamento Assinatura

Prof. Dr.

Julgamento Assinatura

Prof. Dr.

Julgamento Assinatura

Prof. Dr.

Julgamento Assinatura 


\section{Carolina Paes Torres Mantovani}

DADOS CURRICULARES

NASCIMENTO

FILIAÇÃo

1997-2000

2001-2003

2002-2005

2008-2011
17 de fevereiro de 1978, São Paulo - SP

Moacir Antonio Torres

Sonia Regina Paes Torres

Curso de Graduação

Faculdade de Odontologia de Ribeirão Preto da Universidade de São Paulo - FORP/USP

\section{Especialização em Odontopediatria}

Associação Paulista de Cirurgiões Dentistas - Regional de São Carlos/São Paulo

Curso de Pós-Graduação em Odontopediatria, nível de Mestrado Faculdade de Odontologia de Ribeirão Preto da Universidade de São Paulo - FORP/USP

\section{Doutorado em Ciências}

Programa: Odontopediatria

Área de Concentração: Odontopediatria

Faculdade de Odontologia de Ribeirão Preto da Universidade de São Paulo - FORP/USP 
A Deus...

Sob a direção de um forte general, não haverá jamais soldados fracos. (Sócrates) 


\section{Dedico este tRABalHo}

\section{Aos meus pais Sonia e Moacir...}

Obrigada por estarem tão intensamente por perto e me apoiarem por mais esta etapa que escolhi trilhar, respeitando minhas decisões, meus momentos. Vocês são minha inspiração contínua. Meus exemplos de dignidade, bondade, família e tantos outros predicados. Vocês são a melhor família que Deus poderia me dar de presente. Amo vocês!!!

\section{Ao meu irmão Fernando...}

Obrigada por existir em minha vida... pelo seu carinho de sempre. É muito bom ter você tão bem assim. Te amo demais!!!

\section{A meu amor...,Ricardo}

Mais uma etapa vencida, mais uma vez você do meu lado, respeitando minhas ausências, me "cobrindo" na rotina familiar, nos nossos fins de semana, para suprir minhas ausências com nosso filho. Obrigada por ser um incansável incentivador, um companheiro dia a dia. Obrigada por seu amor, que me faz sentir a melhor pessoa deste mundo. Nada seria possível sem você, pois é parte disso.

Ri, meu amor por você é imenso e hoje, se materializou no presente divino que são nossos filhos. Nunca vai ter fim...

\section{As meus filhos... Enrico e Betina}

Enrico, meu "príncipe", e Betina, minha luz "consagrada por Deus"...

Ter vocês na minha vida foi o maior presente que eu podia receber do Divino.

Vivo e respiro por vocês, pela dádiva de sentir este amor...

Aos meus avós Seraphim Torres e José Fonseca Paes (in memorian)...

Quantas saudades....

\section{A "minha grande família"...}

Agradeço pela ancoragem que me proporcionam, pelo amor que me dedicam e por estarem sempre presentes em minha vida.

\section{Ser profundamente amado por alguém nos dá força; amar alguém profundamente nos dá coragem.}




\section{AgradeCimentos}

\section{"Agradecer é admitir que houve um momento em que se precisou de alguém, e reconhecer que o homem jamais poderá lograr de si o dom de ser autossuficiente".}

A Profa. Dra. Maria Cristina Borsatto, minha orientadora, minha amiga, minha sempre "mãe". Cris, depois de tantos anos de convívio, ainda não encontro palavras para expressar o meu imenso carinho por você. $A$ vida passa, as situações acontecem, mas a semente que um dia foi plantada permanece quando dela emana apenas bons sentimentos... e a nossa amizade é assim, repleta de bons sentimentos!!! Você continua sendo meu exemplo de pesquisadora com todos os seus predicados em sua ética, honestidade e sabedoria, meu exemplo como professora e meu exemplo como pessoa, em sua bondade e em seu imenso coração. É com muito carinho que te agradeço por mais esta "orientação" em minha vida!!!

A Profa. Dra. Regina Guenka Palma Dibb, minha coorientadora. Re, desde a graduação você tem um lugar especial na minha vida e hoje, ao final desta etapa, tenho orgulho de dizer que você foi peça fundamental em cada etapa da minha vida acadêmica. Tenho um imenso carinho por você, minha amiga e por você, minha sempre orientadora. O seu caráter e honestidade me servem de exemplo. Obrigada à professora Regina, à pesquisadora Regina e a amiga Regina de sempre. Estendo meus agradecimentos também ao Alessando Dibb, que desde meu mestrado, vem contribuindo substancialmente com suas sugestões "químicas", sempre engrandecendo nossos trabalhos. Obrigada, pequena Sophia, Stephanie e Oliver por dividir sua mãe comigo!!!

A minha querida amiga, Jaciara Miranda Gomes da Silva, por fazer parte da minha vida, em todos os aspectos. Te agradecer pelo que tem feito por mim nunca será o suficiente. A sua bondade, sinceridade, dedicação ao ser humano, incontestáveis, são 
reflexos de uma família maravilhosa que está por traz de você. Agradeço a Deus por ter me permitido te encontrar e sedimentar uma relação de amizade que não tem limites, fundamentada em um carinho incondicional. Já, obrigada, obrigada, obrigada !!! Tudo foi muito mais "fácil" e agradável com você por perto...

A minha querida amiga, Fátima Rizóli, a quem não tenho como a agradecer. Obrigada Fá, por todos os cuidados, todo o carinho que recebo diariamente. Obrigada Fá, por ser esta pessoa tão especial e ter me "adotado" com tanto amor. Por cuidar de mim, de toda a minha familia, com tanta sinceridade e carinho. Você existir na minha vida, foi um dos meus melhores presentes!!!

A minha querida, Profa. Dra. Maria Angélica Hueb de Menezes Oliveira. Amiga, mais que nunca, hoje, ainda tenho você como um exemplo de como ser profissional, esposa, mãe e mulher sem perder a essência de "ser humano" em seu mais pleno sentido. Eu é quem gostaria de ter você como minha irmã... e Deus nos dá esta oportunidade, pois além de nos dar os parentes de sangue, nos concede escolher nossa familia pelos laços do coração. Obrigada, minha amiga-irmã, por tudo... e Nossa Senhora das Medalhas proteja "nossa" familia sempre!!!

A minha querida amiga Renata Pereira Ramos, que desde o muito faz parte de minha vida, mais de uma década contando com sua amizade! Re, obrigada por estar presente sempre na minha caminhada profissional e pessoal e pelo imenso carinho que você tem por mim, que é verdadeiramente recíproco.

Aos meus amigos Prof. Dr. José Tarcísio Ferreira, Marta Contente e Rodrigo Galo, que desde muito temos tido a oportunidade de estarmos juntos, trilhando por caminhos próximos. Obrigada por todas as horas, todos os momentos, a amizade cúmplice de todos estes anos!

Ao Prof. Dr. Paulo Nelson Filho, meu querido "chefe", sempre meu mestre por ser um exemplo de professor em seu sentido mais completo. Só tenho a te agradecer pelas portas sempre abertas, pela compreensão e respeito que você sempre me dedicou. Obrigada, Paulo, por todo o carinho e por tudo o que você tem feito por mim. 
À Profa. Dra. Aldevina Campos de Freitas, pelo exemplo de dedicação em tudo que faz, dinamismo, competência. Obrigada, professora, pelo carinho, respeito e consideração despendida a mim, sempre!

A Profa. Dra. Kranya Victoria Serrano Díaz. Minha querida amiga, de muitos anos, de Odontologia e de vida. Poder compartilhar momentos com você foi sempre muito bom. Obrigada por seu carinho, atenção, preocupação e honestidade com nossa amizade, traduzidos em tantos momentos.

À Profa. Dra. Alexandra Mussolino de Queiroz. Obrigada Danda, pelo carinho, apoio e incentivo de sempre. É muito bom trabalhar com você!

A Profa. Dra. Andrea Cândido dos Reis. Obrigada por me fazer enxergar, em uma conversa pelos corredores da FORP, que o mais difícil eu tinha sido abençoada em realizar, que é a dádiva de ter um filho em meu ventre, e que todos os outros fatos em minha vida, eram fáceis e possivelmente atingíveis.

Aos amigos Alessandra Afonso Corrêa, Patrícia Marchi, Juliana Faraoni, César Penazzo Lepri e Walter Raucci Neto. Obrigada pelo convívio agradável e pelos auxílios de sempre.

Ao Sr. Reginaldo Santana da Silva, do Departamento de Odontologia Restauradora da Faculdade de Odontologia de Ribeirão Preto da Universidade de São Paulo, pelo auxílio na execução dos procedimentos experimentais e pela alegre companhia do dia a dia. É muito bom poder contar com amigos para todas as horas.

Aos técnicos Edson Volta e Ricardo de Souza Antunes do Laboratório LIPEN, da Faculdade de Odontologia de Ribeirão Preto da Universidade de São Paulo, por me estenderem a mão em um momento de aflição, com muita competência e dedicação.

Ao Prof. Dr. Luis Eduardo Silva Soares, do Laboratório de Espectroscopia Vibracional Biomédica - LEVB da Universidade do Vale do Paraíba, pela disposição em colaborar com este trabalho. 
Ao Prof. Dr. Luiz Carlos Pardini, obrigada pela colaboração imprescindível na parte experimental desta tese, pelo exemplo de professor desde minha graduação e pela disposição e entusiasmo em estudar novos projetos, abrindo suas portas para inserir a Odontopediatria em sua linha de pesquisa.

Aos amigos Cíntia Guimarães de Almeida e ao Prof. Dr. Luciano Bachman, obrigada pela sempre disposição em ajudar, esclarecer e pela amizade carinhosa que surgiu deste convívio.

As minha amigas, Vilma Barcelos Otani e Ana Paula Vieira. Obrigada meninas, pelo bom dia de todas as manhãs, pelo convívio mais que agradável, por "somar" harmonia na nossa rotina de trabalho.

Aos colegas do Mestrado e Doutorado em Odontopediatria da Faculdade de Odontologia de Ribeirão Preto da Universidade de São Paulo, pela convivência agradável que tivemos durante esses anos.

Aos docentes do Departamento de Clínica Infantil, Odontologia Preventiva e Social da Faculdade de Odontologia de Ribeirão Preto da Universidade de São Paulo, Profa. Dra. Sada Assed; Profa. Dra. Léa Assed Bezerra da Silva, Profa. Dra. Aldevina Campos Freitas; Profa. Dra. Maria Cristina Borsatto; Profa. Dra. Kranya Victória Diaz Serrano; Prof. Dr. Paulo Nelson Filho, Profa. Alexandra Mussolino de Queiroz, Profa. Dra. Raquel Assed Bezerra da Silva, Profa. Dra. Andiara de Rossi, Profa. Dra. Maria Conceição Pereira Saraiva, Profa. Dra. Prof. Dr. Adilson Thomazinho, Prof. Dr. José Tarcísio Lima Ferreira, Profa. Dra. Mírian Aiko Nakame Matsumoto, Profa. Dra. Maria Bernadete Sasso Stuani e Prof. Dr. Fábio Lourenço Romano. Obrigada pelo convívio agradável no dia a dia e pela orientações e ensinamentos.

Aos funcionários da Faculdade de Odontologia de Ribeirão Preto da Universidade de São Paulo: Benedita Viana Rodrigues, Carmo Eurípedes Terra Barreto, Cleber Barbosa Rita, Fátima Aparecida Jacinto Daniel, Fátima Aparecida Rizóli, Francisco Wanderley Garcia de Paula e Silva, Filomena Leli Placciti, José Aparecido Neves do Nascimento, José Carlos Ferreira Junior, José Henrique Loureiro, Julio César Souza da Matta, Marco Antonio dos Santos, Matheus Morelli Zanela, Micheli 
Cristina Leite Ravanholo, Nilza Letícia Magalhães, Renata Aparecida Fernandes Rodrigues, Renata Cristina Rosa e Vera Ribeiro do Nascimento. Obrigada pela mão sempre estendida, pelo bom humor e carinho que me dedicam, dia após dia.

Às funcionárias da Seção de Pós-Graduação da Faculdade de Odontologia de Ribeirão Preto da Universidade de São Paulo, Isabel Cristina Galino Sola e Regiane Cristina Moi Sacilotto, pelo carinho e atenção prestada.

A Coordenação do Curso de Pós-Graduação da Faculdade de Odontologia de Ribeirão Preto da Universidade de São Paulo, na pessoa da Profa. Dra. Léa Assed Bezerra da Silva, pela oportunidade de ser aluna deste programa.

À Coordenação do Curso de Pós-Graduação em Odontopediatria da Faculdade de Odontologia de Ribeirão Preto da Universidade de São Paulo, na pessoa da Profa. Dra. Léa Assed Bezerra da Silva. Pelo determinismo e empenho em conseguir o reconhecimento merecido deste curso, composto por professores de inigualável capacidade de ensinar.

A Faculdade de Odontologia de Ribeirão Preto da Universidade de São Paulo, escola que tenho profundo apreço, por aqui me encantei desde o dia da matrícula pra o curso de graduação, tive a felicidade de dar continuidade a minha formação, neste curso de pós-graduação, e hoje, com imenso prazer é aqui que devolvo todos os ensinamentos que me ofereceu. Obrigada, querida FORP-USP, sinto-me em casa!!!

Ao Prof. Dr. Osvaldo Luiz Bezzon, na pessoa do Diretor da Faculdade de Odontologia de Ribeirão Preto da Universidade de São Paulo.

Aos meus pacientes "especiais" e minhas crianças, por serem o real motivo da minha dedicação e realização com a profissão que escolhi.

A todos que, de alguma forma, contribuíram para a realização desta etapa profissional... Muito Obrigada! 


\section{Resumo}

Torres-Mantovani CP. Análise das propriedades físicas e químicas da dentina de dentes decíduos e permanentes - estudo in vitro [tese]. Ribeirão Preto: Faculdade de Odontologia de Ribeirão Preto da Universidade de São Paulo; 2011.

A exata composição e a micromorfologia da dentina de dentes decíduos ainda são pouco estudadas e conhecidas, e a literatura existente apresenta achados controversos. Os resultados de pesquisas realizadas em dentes permanentes são frequentemente extrapolados para dentes decíduos, sendo que a maioria dos trabalhos explora estes substratos de maneira isolada. É necessário, portanto, conhecer a composição e a estrutura da dentina de dentes decíduos e determinar em quais aspectos este tecido realmente difere da dentina de dentes permanentes. A comparação dos dois substratos é fundamental para que sejam estabelecidos protocolos preventivos e restauradores, bem como no desenvolvimento de materiais e técnicas específicos e efetivos para dentes decíduos e permanentes. Assim, o objetivo do presente estudo foi realizar uma análise comparativa in vitro da dentina de dentes decíduos e permanentes, avaliando suas propriedades físicas e químicas. As propriedades físicas analisadas foram a Permeabilidade $(n=15)$, a Microdureza ( $n=10)$, a Radiodensidade $(n=10)$ e a Resistência Coesiva (Ultimate Tensile Strength) ( $n$ = 15). As propriedades químicas foram o mapeamento de superfície dentinária por Microfluorescência de Raios-X por Energia Dispersiva $(\mu F R X)(n=10)$ e Espectroscopia Raman por Transformada de Fourier (FT-Raman) ( $n=10)$. Os dados foram analisados quanto a sua distribuição e homogeneidade. Na análise de Microdureza, a distribuição dos dados não foi normal e empregou-se o teste não paramétrico de Mann-Whitney para a análise estatística. Para os demais testes, a distribuição dos dados apresentou-se normal e homogênea. Assim, para a análise de Permeabilidade e Radiodensidade foi utilizada Análise de Variância a um critério: tipo de substrato $(p<0,05)$; para o teste de Microtração, empregou-se Análise de Variância a dois critérios $(p<0,05)$ : tipo de substrato e profundidade; os dados de Microfluorescência de Raios-X por Energia Dispersiva e Espectroscopia Raman por Transformada de Fourier foram analisados pelo teste $\mathrm{t}$ de Student. Considerando-se as limitações de um estudo in vitro, os achados demonstraram que em relação às propriedades físicas, a dentina de dentes decíduos apresentou maior 
permeabilidade, menor radiodensidade e menor resistência coesiva quando comparada à dentina de dentes permanentes. Entretanto, a microdureza foi semelhante para os dois tecidos dentinários. Para as propriedades químicas avaliadas, constatou-se que a dentina de dentes decíduos apresentou menor conteúdo em peso de Cálcio (\%) e da proporção $\mathrm{Ca} / \mathrm{P}$ (\%) e maior porcentagem em conteúdo de Carbonato. No entanto, a quantidade de Fósforo, Fosfato e o conteúdo orgânico, não diferiram dos resultados obtidos na dentina de dentes permanentes.

Palavras-Chave: Dentina, Dente decíduo, Dente permanente, Propriedades químicas, Propriedades físicas. 


\section{ABSTRACT}

Torres-Mantovani CP. Analysis of the physical and chemical properties of the dentin of primary and permanent teeth - an in vitro study [tese]. Ribeirão Preto: Faculdade de Odontologia de Ribeirão Preto da Universidade de São Paulo; 2011.

There is still little research and information on the precise composition and the micromorphology of the dentin of primary teeth, and the existing literature reveals controversial findings. The results of studies in permanent teeth are frequently extrapolated to primary teeth, and the majority of works explores these substrates alone. It is thus necessary to know the composition and structure of the dentin of primary teeth and determine in which ways this tissue actually differs from the dentin of permanent teeth. Comparison of these substrates under different aspects is fundamental to establish preventive and restorative protocols, as well as materials and techniques that are specific and effective for primary and permanent teeth. Therefore, the aim of the present in vitro study was to perform a comparative analysis of the dentin of primary and permanent teeth by evaluating its physical and chemical properties. For the physical analysis, Permeability ( $\mathrm{n}$ $=15)$, Microhardness $(n=10)$, Radiodensity $(n=10)$ and Ultimate Tensile Strength $(n=$ $15)$ tests were performed. Chemical analysis comprised dentin surface mapping by Energy Dispersive X-ray Microfluorescence $(\mu \mathrm{FRX})(\mathrm{n}=10)$ and Fourier transform (FT) Raman spectroscopy $(n=10)$. Data distribution and homogeneity were analyzed. In the Microhardness test, data distribution was not normal and the Mann-Whitney non-parametric test was used for statistical analysis. For the other tests, data distribution was normal and homogenous. Thus, one-way analysis of variance (type of substrate) was used for the Permeability and Radiodensity tests $(p<0.05)$; two-way analysis of variance (type of substrate and depth) was used for the Microtensile Bond Strength test $(p<0.05)$; data from Energy Dispersive X-ray Microfluorescence $(\mu \mathrm{FRX})(\mathrm{n}=10)$ and Fourier transform $(F T)$ Raman spectroscopy were analyzed using the Student's t-test. Considering the limitations of an in vitro investigation, the findings revealed that with respect to the physical properties, the dentin of primary teeth presented greater permeability, lower radiodensity and lower ultimate bond strength of substrate when compared with the dentin of permanent teeth. Nevertheless, the microhardness was similar for both dentin tissues. Regarding the chemical 
properties, the dentin of primary teeth presented a smaller amount of Calcium and $\mathrm{Ca} / \mathrm{P}$ (wt\%) and, greater amount of Carbonate. However, the amount of Phosphorus and Phosphate and the organic content, did not differ from the results obtained in the dentin of permanent teeth.

KeY-WORDS: Dentin; Tooth, deciduous; Tooth, permanent; Chemical properties; Physical properties 


\section{SUMÁRIO}

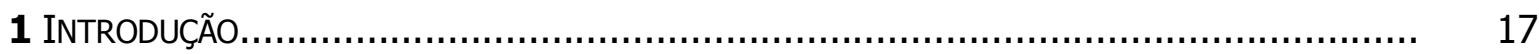

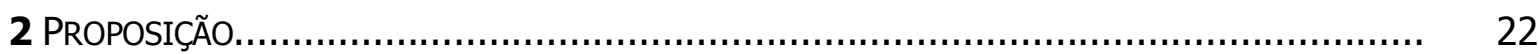

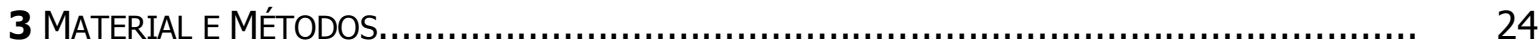

3.1 ASPECTOS ÉTICOS........................................................................... 25

3.2 DELINEAMENTO EXPERIMENTAL........................................................... 25

3.3 SELEÇÃO DOS DENTES.......................................................................... 26

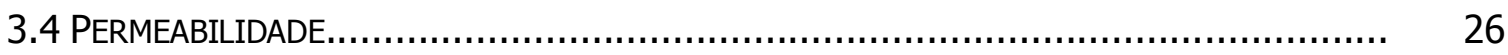

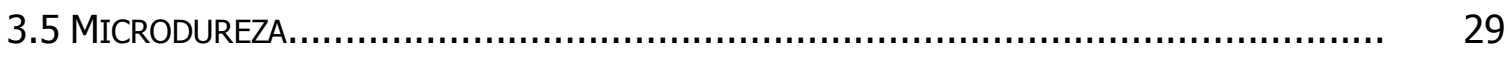

3.6 RADIODENSIDADE ...................................................................... 32

3.7 RESISTÊNCIA COESIVA (ULTIMATE TENSILE STRENGTH)...................................... 35

3.8 MICROFLUORESCÊNCIA DE RAIOS-X POR ENERGIA DISPERSIVA ( $\mu$ EDX)....................... 39

3.9 ESPECTROSCOPIA RAMAN POR TRANSFORMADA DE FOURIER.................................. 40

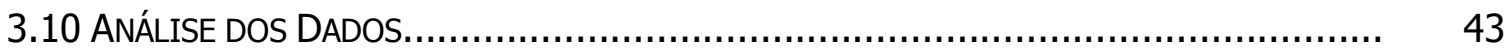

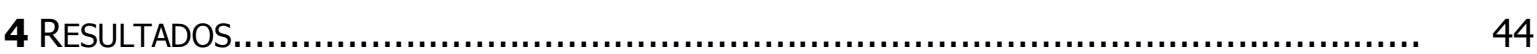

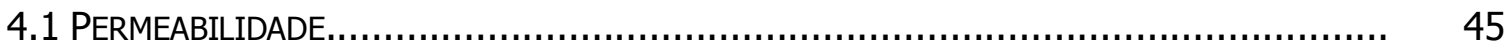

4.2 MICRODUREZA......................................................................... 46

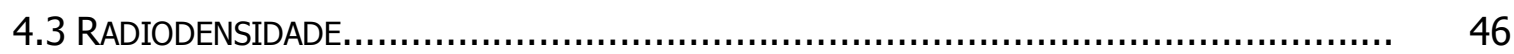

4.4 RESISTÊNCIA COESIVA (ULTIMATE TENSILE STRENGTH)...................................... 47

4.5 MICROFLUORESCÊNCIA DE RAIOS-X POR ENERGIA DISPERSIVA ( $\mu$ EDX)...................... 47

4.6 ESPECTROSCOPIA RAMAN POR TRANSFORMADA DE FOURIER.................................... 49

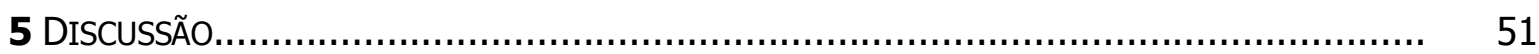

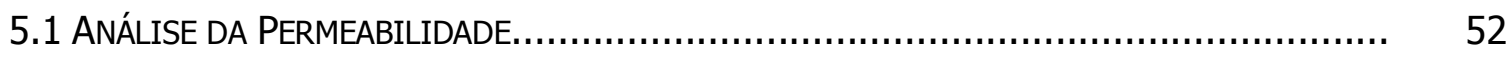

5.2 ANÁLISE DA MICRODUREZA................................................................ 54

5.3 ANÁLISE DA RADIODENSIDADE............................................................... 56

5.4 ANÁLISE DA RESISTÊNCIA COESIVA (ULTIMATE TENSILE STRENGTH)......................... 58

5.5 ANÁLISE DA MICROFLUORESCÊNCIA DE RAIOS-X POR ENERGIA DISPERSIVA ( $\mu$ EDX) E ESPECTROSCOPIA RAMAN POR TRANSFORMADA DE FOURIER.................................... 61

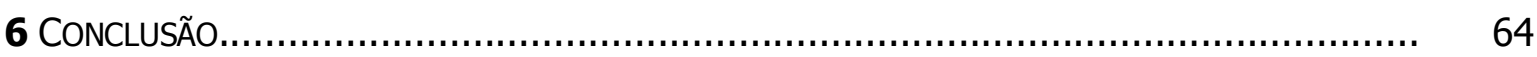

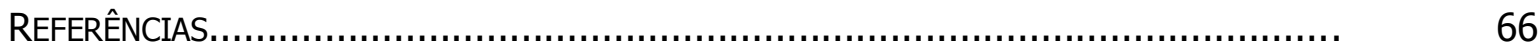

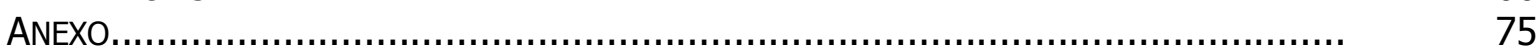




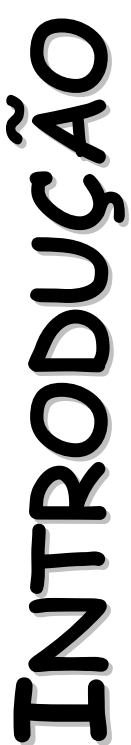




\section{INTRODUÇÃO}

Os tecidos dentários e suas estruturas de suporte são formados como resultado da interação entre o epitélio bucal e o ectomesênquima, durante a odontogênese, tendo cada tecido um processo específico de formação. Assim, amelogênese, dentinogênese e cementogênese referem-se, respectivamente, à formação do esmalte, da dentina e do cemento, tecidos dentários mineralizados.

A dentina é um tecido conjuntivo avascular especializado e mineralizado, de origem ectomesenquimática, que constitui a maior parte do dente. É recoberta pelo esmalte na sua porção coronária e pelo cemento na porção radicular. Sua superfície interna delimita a cavidade pulpar. Apresenta-se como um substrato consideravelmente complexo, cuja principal função estrutural é fornecer suporte para o esmalte dentário. Para tal finalidade, a dentina necessita ser, ao mesmo tempo, um tecido duro, porém com certa elasticidade, sendo que tais propriedades são fornecidas pelo equilíbrio entre os componentes minerais e orgânicos que a formam.

Constitui um tecido biológico hidratado - composto por $70 \%$ de material inorgânico, $18 \%$ de material orgânico e $12 \%$ de água, em peso - cujas propriedades e componentes estruturais variam de acordo com a área analisada. Seu componente inorgânico é constituído por cristais de hidroxiapatita, enquanto a porção orgânica contém principalmente colágeno tipo I, além de frações de colágeno tipo III e V, glicoproteínas e proteoglicanos e proteínas não colágenas (Mjör, 2009).

A composição estrutural da dentina inclui canalículos orientados, denominados túbulos dentinários. Os túbulos que convergem em direção à câmara pulpar, vão sendo formados à medida que os odontoblastos vão sintetizando a matriz dentinária, centripetamente, deixando no interior destes túbulos um prolongamento celular, denominado prolongamento odontoblástico, e um fluido tecidual derivado da polpa, responsável por manter certa pressão interna. Os túbulos dentinários são vias de difusão de agentes nocivos e de transmissão de estímulos sensitivos ao tecido pulpar. A configuração anatômica tubular da dentina confere a este tecido uma peculiaridade, que o difere dos demais tecidos mineralizados do corpo humano (Pashley e Livingston, 1978a; Pashley e Livingston, 1978b; Mjör, 2009).

Durante a formação da dentina, os odontoblastos sintetizam inicialmente a matriz proteica, que posteriormente será mineralizada por uma deposição de cristais de Fosfato 
de Cálcio. Cada túbulo dentinário está circunscrito por uma dentina hipermineralizada, denominada dentina peritubular, e, entre eles, encontra-se a dentina intertubular (Tronstad, 1973; Mjör, 2009).

Como os túbulos dentinários convergem em direção à câmara pulpar, a densidade tubular e a orientação variam de acordo com a localidade no tecido (Marshall et al., 1997; Menezes-Oliveira, 2009). Desta forma, as variações dos componentes estruturais e morfológicos ao longo do substrato dentinário resultaram em variações importantes nas suas propriedades como permeabilidade (Tagami et al., 1992), umidade, área superficial disponível para adesão (Nakamichi et al., 1983; Causton, 1984; Suzuki e Finger, 1988; Tagami et al., 1990; Giannini et al., 2001), além das propriedades mecânicas (Pashley et al., 1985).

Neste contexto, Ryou et al. (2011) investigaram a importância da microestrutura e da composição química da dentina de dentes permanentes em diferentes profundidades nas propriedades mecânicas deste substrato. Por meio de análise da microdureza Vickers, do módulo de elasticidade e da Espectroscopia no Infravermelho por Transformada de Fourier, os autores observaram que a dentina profunda, próxima à câmara pulpar, apresentou um menor conteúdo de colágeno em comparação à dentina superficial ou periférica, o que justificaria os menores valores de resistência mecânica, ou seja, o menor módulo elasticidade e a menor resistência à tensão e à fratura apresentados pela dentina profunda.

A dentina do dente decíduo é formada e desenvolvida semelhantemente ao dente permanente por apresentarem a mesma origem embriológica. Desta forma, os resultados das pesquisas utilizando dentes permanentes são geralmente extrapolados para os dentes decíduos.

Todavia, e em grande parte devido aos esforços de grupos de pesquisadores na área da odontopediatria, a literatura específica começou a relatar comportamentos diferentes da dentina de dentes decíduos em comparação ao dente permanente frente aos desafios ácidos, procedimentos restauradores e adesivos, bem como ao stress mecânico (Mejàre e Stenlung, 2000; Mejàre et al., 2001; Burrow et al., 2002; Senawongse et al., 2004; Courson et al., 2005; Subba Reddy e Chowdhary, 2010). Neste contexto, alguns autores observaram que a resistência da interface adesiva da dentina de dentes decíduos utilizando diferentes sistemas adesivos apresentou valores inferiores aos observados nos dentes permanentes (Burrow et al., 2002; Senawongse et al., 2004; Courson et al., 2005), enquanto Nör et al. (1997) inferiram que a dentina do dente decíduo parece ser mais reativa ao condicionamento ácido. 
Mas, quais as diferenças entre estes substratos seriam responsáveis pelos resultados encontrados na literatura?

Alguns autores compararam a estrutura dentinária de dentes decíduos e permanentes. E, por meio de uma revisão da literatura, Araújo et al. (1995) relataram que o padrão de mineralização (velocidade e quantidade) do dente decíduo é cerca de $1 / 5$ menor que o verificado para o dente permanente. Isto porque o dente decíduo apresenta ciclo biológico reduzido. Em média, a formação e mineralização da coroa de um dente decíduo são de no mínimo seis meses (incisivo central) e no máximo quatorze meses (segundo molar decíduo), enquanto a média para o dente permanente é de 3 a 4 anos. Neste sentido, Ankger et al. (2004) observaram 59,3\% de conteúdo mineral na dentina de dentes decíduos em comparação a 70\% para o dente permanente, relatado por Mjör (2009).

Ainda, Garberoglio e Brännström (1976) e Koutsi et al. (1994) afirmaram que os túbulos dentinários nos dentes decíduos apresentam-se menores e em menor número em relação à dentina de dentes permanentes. Neste contexto, Sumikawa et al. (1999) relataram que a densidade numérica dos túbulos dentinários é maior em dentes decíduos, com diminuição da área de dentina intertubular. Koutsi et al. (1994) observaram que a condutibilidade hidráulica da dentina é maior nos dentes permanentes, concluindo que a dentina dos dentes decíduos é menos permeável que a dos dentes permanentes. De acordo com Hirayama et al. (1986), a dentina peritubular do dente decíduo mostrou-se 2 a 5 vezes mais espessa, e os túbulos dentinários apresentaram-se com diâmetro menor em comparação ao dente permanente.

Subba Reddy e Chowdhary (2010) observaram a dentina de dentes decíduos e permanentes por meio da análise de microscopia de luz polarizada e microscopia de transmissão. Dentre os achados histológicos, verificaram que a dentina de dentes decíduos apresentou a direção dos túbulos dentinários com trajeto sinuoso (curvatura em "s") em $26,7 \%$ das amostras, e a maioria (73,3\%), túbulos com trajetos retos. Nos dentes permanentes, em $100 \%$ das amostras, foi observado o trajeto sinuoso dos túbulos. Considerando que o trajeto sinuoso dos túbulos consiste no curso percorrido pelos odontoblastos durante o processo de odontogênese, da dentina periférica em direção à câmara pulpar, especula-se que a ausência da curvatura nos dentes decíduos possa ser explicada pela menor espessura da dentina que estes dentes apresentam.

Diante do exposto, pode-se observar que a literatura além de escassa apresenta resultados controversos e sem padronização da metodologia no que diz respeito aos estudos relacionados ao conhecimento da composição química, estrutura morfológica e propriedades 
físicas da dentina de dentes decíduos, bem como sua comparação com os dentes permanentes.

A utilização de metodologias e técnicas mais específicas e precisas, fornecem resultados mais apurados para a avaliação, compreensão e interpretação das análises destes substratos. Desta forma, a comparação entre a dentina do dente decíduo e a do dente permanente em um mesmo trabalho é essencial para a padronização do método de análise da pesquisa e, portanto, para uma avaliação efetiva entre estes tecidos mineralizados.

Assim, é de fundamental importância conhecer em detalhes as diferenças entre os substratos nos quais os profissionais, principalmente os odontopediatras, atuam para que sejam estabelecidos protocolos preventivos e restauradores, bem como para que sejam desenvolvidos materiais e técnicas específicos e efetivos para cada substrato. 
2
un
1
0
0
0
0 


\section{Proposição}

O objetivo do presente estudo foi realizar uma análise comparativa in vitro das propriedades físicas e químicas da dentina de dentes decíduos e permanentes, por meio da avaliação da permeabilidade, microdureza, radiodensidade, força coesiva e, conteúdo orgânico (Amida I) e inorgânico (Cálcio, Fósforo, Carbonato e Fosfato) destes substratos. 
0
0
2
3

U

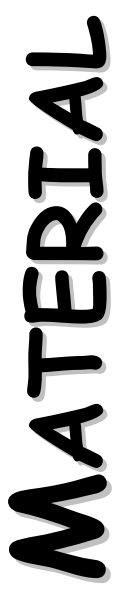




\section{Material e MÉtodos}

\subsection{AsPectos Éticos}

O presente estudo foi inicialmente submetido à avaliação pelo Comitê de Ética em Pesquisa da Faculdade de Odontologia de Ribeirão Preto da Universidade de São Paulo, processo número 2010.1.540.58.9, recebendo parecer favorável (Anexo A).

\subsection{Delineamento EXPERIMENTAL}

O fator em estudo foi o tipo de substrato em dois níveis: dentina de dentes decíduos e dentina de dentes permanentes.

A amostra do experimento foi constituída de 70 corpos de prova. As variáveis de resposta quantitativas foram:

- análise das propriedades físicas da dentina por meio dos testes de:

- Permeabilidade

$$
(n=15)
$$

- Microdureza

$$
(\mathrm{n}=10)
$$

- Radiodensidade

$$
(n=10)
$$

- Resistência Coesiva (Ultimate Tensile Strength)

$$
(n=15)
$$

- análise da composição química por meio de:

- Microfluorescência de Raios-X por Energia Dispersiva ( $\mu$ EDX) $(\mathrm{n}=10)$

- Espectroscopia Raman por Transformada de Fourier (FT-Raman) $(n=10)$ 


\subsection{SELEÇÃo dOS DENTES}

Foram selecionados caninos e molares decíduos hígidos, com mais de dois terços de raiz e, caninos e molares permanentes hígidos, irrompidos com a formação radicular completa, armazenados por um período de até seis meses após a avulsão. Estes dentes foram cedidos pelo Banco de Dentes da Faculdade de Odontologia de Ribeirão Preto - USP.

Os dentes foram limpos com curetas periodontais, polidos com pedra pomes e água, com o auxílio de uma escova de Robinson, montada em contra-ângulo, em baixa rotação. Em seguida, foram examinados sob lupa estereoscópica, com aumento de $10 \mathrm{X}$ (Carl Zeiss Jena), com o intuito de detectar alterações de estrutura ou trincas que pudessem comprometer os resultados deste estudo.

\subsection{Permeabilidade}

Para a análise da permeabilidade, 15 caninos decíduos e 15 caninos permanentes foram levados a um equipamento de corte seriado (Minitom, Struers A/S, Copenhagen, DK2610, Denmark), dotado de um disco diamantado (\#7015, KG Sorensen, Barueri, 06454-920, Brasil) refrigerado com água, e tiveram suas raízes seccionadas, $3 \mathrm{~mm}$ abaixo da junção amelocementária. Foram realizadas cavidades nas superfícies vestibulares dos dentes, com auxílio de brocas carbide \#245 montadas em alta rotação, medindo $3 \mathrm{~mm}$ no sentido mesiodistal, $2 \mathrm{~mm}$ no cervico-incisal e $3 \mathrm{~mm}$ em profundidade, de forma a garantir que a parede pulpar estivesse em dentina. Nas regiões cervicais de cada dente, áreas correspondentes à câmaras pulpares, foi realizado um selamento com resina composta Z250 (3M ESPE, St Paul, MN, USA), em porções incrementais, fotopolimerizadas durante 20 s cada. Previamente, estas áreas foram condicionadas com ácido fosfórico a 37\%, durante 30s, lavadas e secas com jatos de ar/água e em seguida, foi aplicado sistema adesivo Single Bond (3M ESPE, St Paul, MN, USA), em duas camadas consecutivas e fotopolimerizado durante 20s. Em seguida, os espécimes foram impermeabilizados com cera pegajosa e esmalte cosmético em duas camadas, permanecendo expostas apenas as paredes internas das cavidades. Foi aplicada solução de EDTA trissódico para realizar a limpeza das paredes do preparo, promovendo a remoção da smear layer e assim, expondo os túbulos dentinários. 
Os espécimes, impermeabilizados, foram imersos em um recipiente contento $10 \mathrm{~mL}$ de solução de sulfato de cobre $10 \%$ (Merck KGaA, Darmstadt, Germany) por 30min, sendo que nos primeiros $5 \mathrm{~min}$ a imersão foi realizada sob vácuo. Em seguida, os espécimes foram secos com papel absorvente e imersos em $10 \mathrm{~mL}$ de solução alcoólica de ácido rubiânico $1 \%$ (Merck KGaA, Darmstadt, Germany), por 30min, sendo que nos primeiros $5 \mathrm{~min}$ a imersão foi realizada sob vácuo. O ácido rubiânico revela os íons cobre formando um composto com coloração que varia do azul escuro ao preto, dependendo da quantidade de íons presente. A profundidade da infiltração destes íons quantifica a permeabilidade do substrato. Após a coloração, os espécimes foram lavados em água destilada, durante $15 \mathrm{~s}$, secos e mantidos em um recipiente vedado, com algodão embebido em amônia por um período de 7 dias, em estufa a $37^{\circ} \mathrm{C}$ (Pécora, 1985).

Após o armazenamento em amônia, os espécimes foram lavados, secos e incluídos em blocos de resina de poliéster (Milflex Indústria Química Ltda., São Bernardo do Campo, São Paulo, Brasil) e, em seguida, foram seccionados em uma máquina de corte (Minitom, Struers A/S, Copenhagen, DK-2610, Denmark) montada com um disco diamantado (Struers A/S, Copenhagen, DK-2610, Denmark) para obtenção de secções transversais com espessura média de $300 \mu \mathrm{m}$. As secções foram lixadas e polidas manualmente utilizando-se lixas d'água de granulação \#600 e \#1200, com a finalidade de obter uma espessura aproximada de 150 $\mu \mathrm{m}$. A espessura foi controlada com o auxílio de um paquímetro universal com leitura eletrônica (Digimatic Caliper/code number 071-467B, Mitutoyo, Suzano, Brazil), com precisão de 0,01 mm. Em seguida, os espécimes foram levados a uma cuba ultrassônica (Ultrasonic Clearner T-1449-D. Odontobrás Ind. e Com., 14075-060, Ribeirão Preto-SP Brasil) durante 5 min e lavados abundantemente em água destilada. Foram então, observados em microscópio óptico (Carl Zeiss, Germany) e suas imagens analisadas utilizando-se o software AxioVision (Zeiss), pertencente ao Laboratório de Dentística do Departamento de Odontologia Restauradora da Faculdade de Odontologia de Ribeirão Preto da Universidade de São Paulo/Brasil, conectado a uma câmara digital (AxioCam MRc - Zeiss)

Para cada dente, foi realizada uma média dos valores obtidos em três secções. Estas medidas foram feitas por meio da mensuração da área de penetração dos íons cobre ao longo da área total de dentina. Assim, a permeabilidade relativa da dentina foi calculada de acordo com a seguinte fórmula:

Permeabilidade $(\%)=$ medida da área da penetração do íon $\times 100$ área total da dentina analisada 
A metodologia deste experimento está representada na Figura 1.
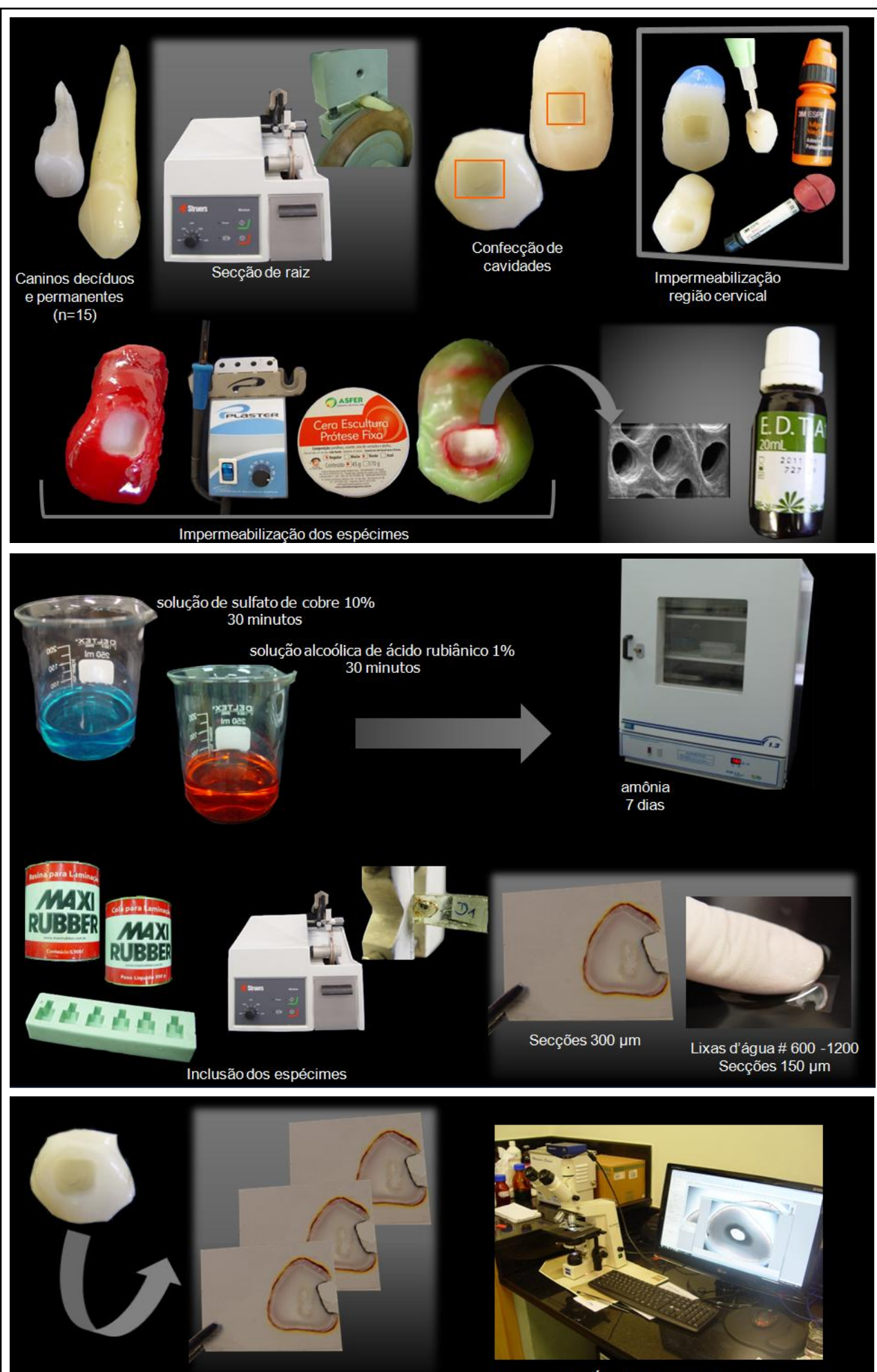

3 secções/dente

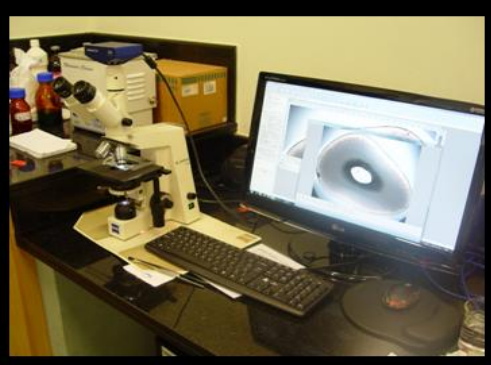

Microscópio Óptico (Carl Zeiss, Germany) Laboratório de Dentística do DOR FORP-USP

Permeabilidade $(\%)=$ medida da área da penetração do íon $\times 100$ espessura total da dentina analisada

FIgURA 1 - Fluxograma da metodologia da análise de permeabilidade. 


\subsection{MICRODUREZA}

Para o teste de microdureza foram utilizados 10 molares decíduos e 10 molares permanentes, que foram levados a um equipamento de corte seriado (Minitom, Struers A/S, Copenhagen, DK-2610, Denmark), dotado de um disco diamantado (\#7015, KG Sorensen, Barueri,06454-920, Brasil) refrigerado com água, e tiveram suas raízes seccionadas, $3 \mathrm{~mm}$ abaixo da junção amelocementária. Posteriormente, as coroas dentárias foram fixadas em uma base de acrílico (lâmina de plexiglass) com auxílio de cera para escultura e, por meio de um disco diamantado adaptado em máquina de corte, sob refrigeração, foram realizados cortes no sentido ocluso cervical, na porção central dos molares, obtendo-se secções de 2 $\mathrm{mm}$ de espessura de cada dente. A espessura foi controlada com o auxílio de um paquímetro universal com leitura eletrônica (Digimatic Caliper/code number 071-467B, Mitutoyo, Suzano, Brazil), com precisão de $0,01 \mathrm{~mm}$. A seguir, os corpos de prova foram polidos com lixas d'água aplicadas em ordem decrescente de abrasividade (\#600 a \#1200), em uma politriz (Politriz Universal Aropol 2 V, Arotec, Cotia, São Paulo, Brasil), sob refrigeração abundante, para em seguida serem polidos com disco de feltro embebido em pasta de alumina de granulações 0,5 $\mu \mathrm{m}$ e 0,03 $\mu \mathrm{m}$ (Struers A/S, Copenhagen, DK-2610, Denmark). Os espécimes foram então levados à cuba ultrassônica (Ultrasonic Clearner T-1449-D. Odontobrás Ind. e Com., 14075-060, Ribeirão Preto-SP Brasil) durante 5min.

Os espécimes foram acomodados com cera utilidade em uma lâmina de vidro e com o auxílio de um paralelômetro (ElQuip, São Carlos-SP, Brasil) a superfície dentinária foi nivelada de forma plana à base da lâmina de vidro. Em seguida, foram fixados com cera para escultura (Kota Ind. e Com. Ltda, São Paulo, Brasil), aquecida em gotejador elétrico (Guelfi Equipamentos, Ribeirão Preto-SP, Brasil), para melhor estabilização durante o teste.

A microdureza da dentina foi avaliada utilizando-se um microdurômetro (HMV-2000/ Shimadzu Corporation, Japan), pertencente ao Laboratório de Dentística do Departamento de Odontologia Restauradora da Faculdade de Odontologia de Ribeirão Preto da Universidade de São Paulo/Brasil, com um penetrador diamantado piramidal tipo Knoop, com carga estática de $10 \mathrm{gf}$, aplicada durante 20s. Foram feitas cinco endentações, distribuídas aleatoriamente, com distância de $100 \mu \mathrm{m}$ entre elas. Foi obtido o valor médio da microdureza de cada dente, sendo desprezados aqueles que apresentaram um valor $5 \%$ acima ou abaixo da média de todos os espécimes, e também aqueles com desvio-padrão interno (entre as cinco marcações de cada dente) acima de $10 \%$ do valor de sua própria média. 
Para medir as endentações realizadas, duas marcas que aparecem no visor do microdurômetro foram sobrepostas aos vértices agudos do losango correspondente à endentação, determinando o comprimento da maior diagonal e, conseqüentemente, o valor de dureza Knoop foi calculado automaticamente pelo software do equipamento, por meio da equação:

\begin{tabular}{|cl|}
\hline $\mathbf{K H N}=\frac{\text { C.C }}{\mathbf{D}^{2}}$ & $\mathrm{KHN}=$ valor de dureza Knoop \\
& $\mathrm{C}$ (constante $)=14,230$ \\
& $\mathrm{C}=10$ gramas \\
& $\mathrm{D}=$ comprimento da maior diagonal da endentação \\
\end{tabular}

A metodologia deste experimento está representada na Figura 2. 


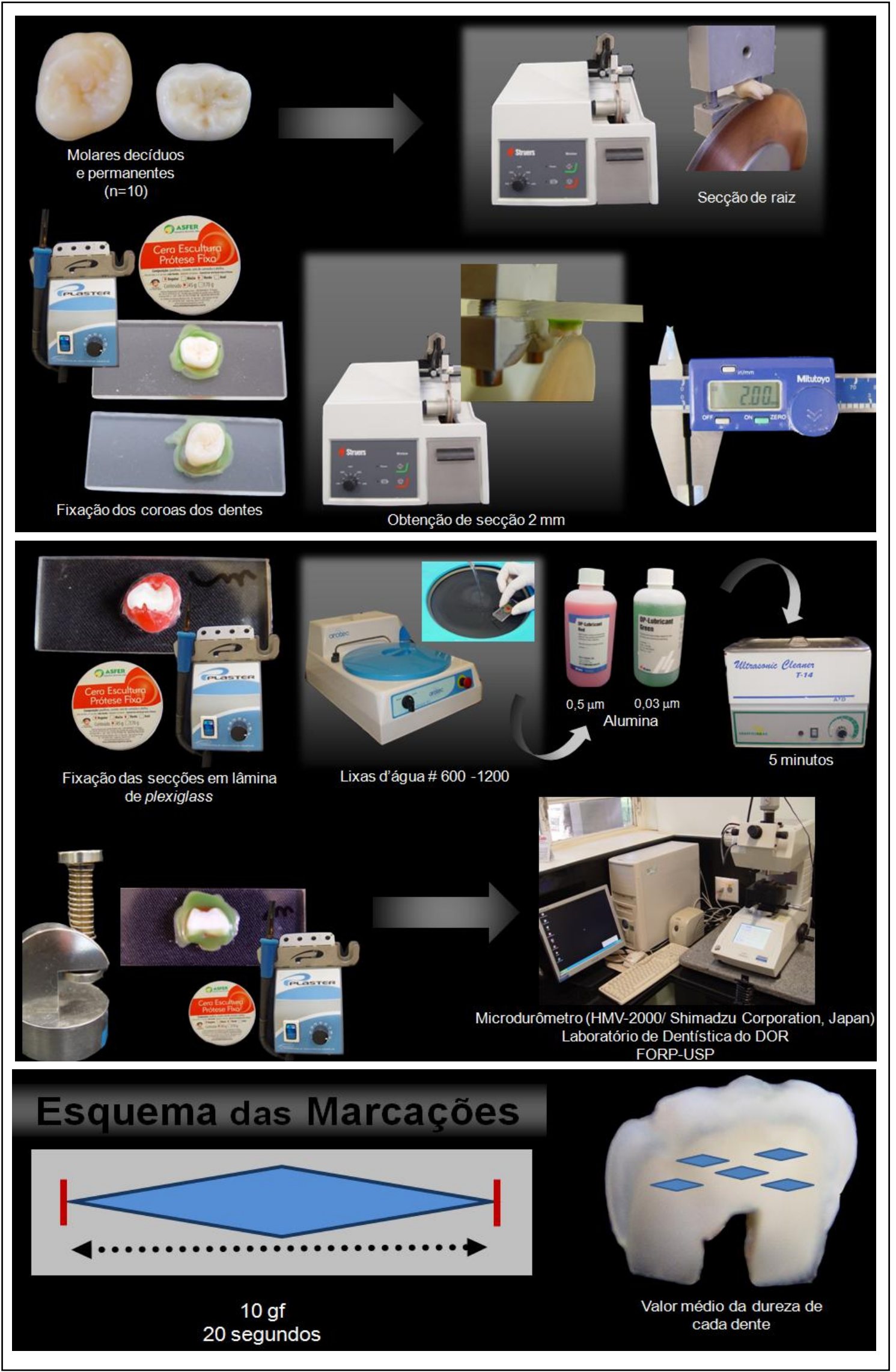

FIgURA 2 - Fluxograma da metodologia da análise de microdureza. 


\subsection{RADIODENSIDADE}

A avaliação da radiodensidade foi realizada em 10 molares decíduos e 10 molares permanentes, que foram levados a um equipamento de corte seriado (Minitom, Struers A/S, Copenhagen, DK-2610, Denmark), dotado de um disco diamantado (\#7015, KG Sorensen, Barueri, 06454-920, Brasil) refrigerado com água, e tiveram suas raízes seccionadas, $3 \mathrm{~mm}$ abaixo da junção amelocementária. Posteriormente, as coroas dentárias foram fixadas em uma base de acrílico (lâmina de plexiglass) com auxílio de cera para escultura (Kota Ind. e Com. Ltda, São Paulo, Brasil), aquecida em gotejador elétrico (Guelfi Equipamentos, Ribeirão Preto-SP, Brasil) e, por meio de um disco diamantado adaptado em máquina de corte, sob refrigeração, foram realizados cortes no sentido ocluso-cervical, na porção central dos molares, obtendo-se secções de $2 \mathrm{~mm}$ de espessura de cada dente. A espessura foi controlada com o auxílio de um paquímetro universal com leitura eletrônica (Digimatic Caliper/code number 071-467B, Mitutoyo, Suzano, Brazil), com precisão de 0,01 mm.

Os espécimes foram posicionados sobre um filme oclusal juntamente com uma escala de alumínio (penetrômetro), medindo $10 \times 32 \mathrm{~mm}$, e escalonada em oito degraus, com espessuras incrementais de 2, 4, 6, 8, 10, 12, 14, $16 \mathrm{~mm}$, de acordo com o protocolo sugerido por Manson-Hing e Bloxom, 1985. Esta escala tem a finalidade de simular, pelas nuances de tonalidades produzidas após a exposição e o processamento das radiografias, as densidades das estruturas da cavidade bucal em relação aos tecidos mineralizados e moles, para a análise laboratorial da qualidade da imagem radiográfica e constatar a homogeneidade dos procedimentos além de detectar as possíveis variações das técnicas e processamentos radiográficos.

Foi realizada uma padronização da posição dos espécimes e da escala de alumínio sobre a película radiográfica. A escala foi colocada no centro da película e cinco espécimes foram posicionados acima e cinco posicionados abaixo desta, de maneira a padronizar que a superfície mesial de cada espécime estivesse sempre voltada para a escala. Foram utilizados filmes oclusais (Insight; Kodak) do grupo sensibilidade "E" (Ref. 1169143/ Lot. 4107494). Estes filmes foram mantidos sob refrigeração conforme recomendação do fabricante, e retirados da mesma com antecedência suficiente para adquirirem a temperatura ambiente antes de sua exposição à radiação. Foi utilizado um aparelho de Raios $\mathrm{X}$ (Siemens Heliodent 60B, São Paulo, Brasil) com cilindro localizador com abertura central de $11 \mathrm{~mm}$ de diâmetro, com $60 \mathrm{Kvp}, 10 \mathrm{~mA}$, pertencente ao Laboratório de Análise e Controle de Imagem em 
Odontologia de Ribeirão Preto da Universidade de São Paulo. Em estudos pilotos, foi determinado um tempo de exposição de 0,10s.

O cilindro localizador foi posicionado perpendicularmente aos objetos a serem radiografados de modo que a distância foco-filme fosse de $20 \mathrm{~cm}$, permitindo assim, que o feixe de radiação incidisse perpendicularmente aos objetos radiografados e ao filme radiográfico. Após a realização das tomadas radiográficas, os filmes foram submetidos ao processamento automático de revelação (A/T 2000 XR; Air Techniques Inc., Melville, NY) seguindo as recomendações do fabricante em relação ao método de processamento tempo/temperatura.

Após a sensibilização e processamento das películas, foram realizadas leituras das densidades ópticas por meio de um fotodensitômetro (Gafchromic, Victoreen, Moedling, Austria) com feixe de luz colimado para $1 \mathrm{~mm}$ de diâmetro. A leitura do fotodensitômetro varia de 0,00 (passagem total do feixe de luz) a 4,36 (bloqueio total do feixe de luz). Três examinadores calibrados, realizaram análise cega das imagens dos espécimes e da escala de alumínio, individualmente e em diferentes dias. Os valores obtidos foram anotados em tabelas.

Inicialmente, foram realizadas duas medidas referentes a cada degrau da escala de alumínio, para em seguida serem feitas as leituras da densidade óptica de cada espécime. Foi obtida uma medida da região mesial, uma da região central e uma da região distal, obtendo-se os valores de densidade óptica de cada dente pela média das três regiões analisadas.

A metodologia deste experimento está representada na Figura 3. 

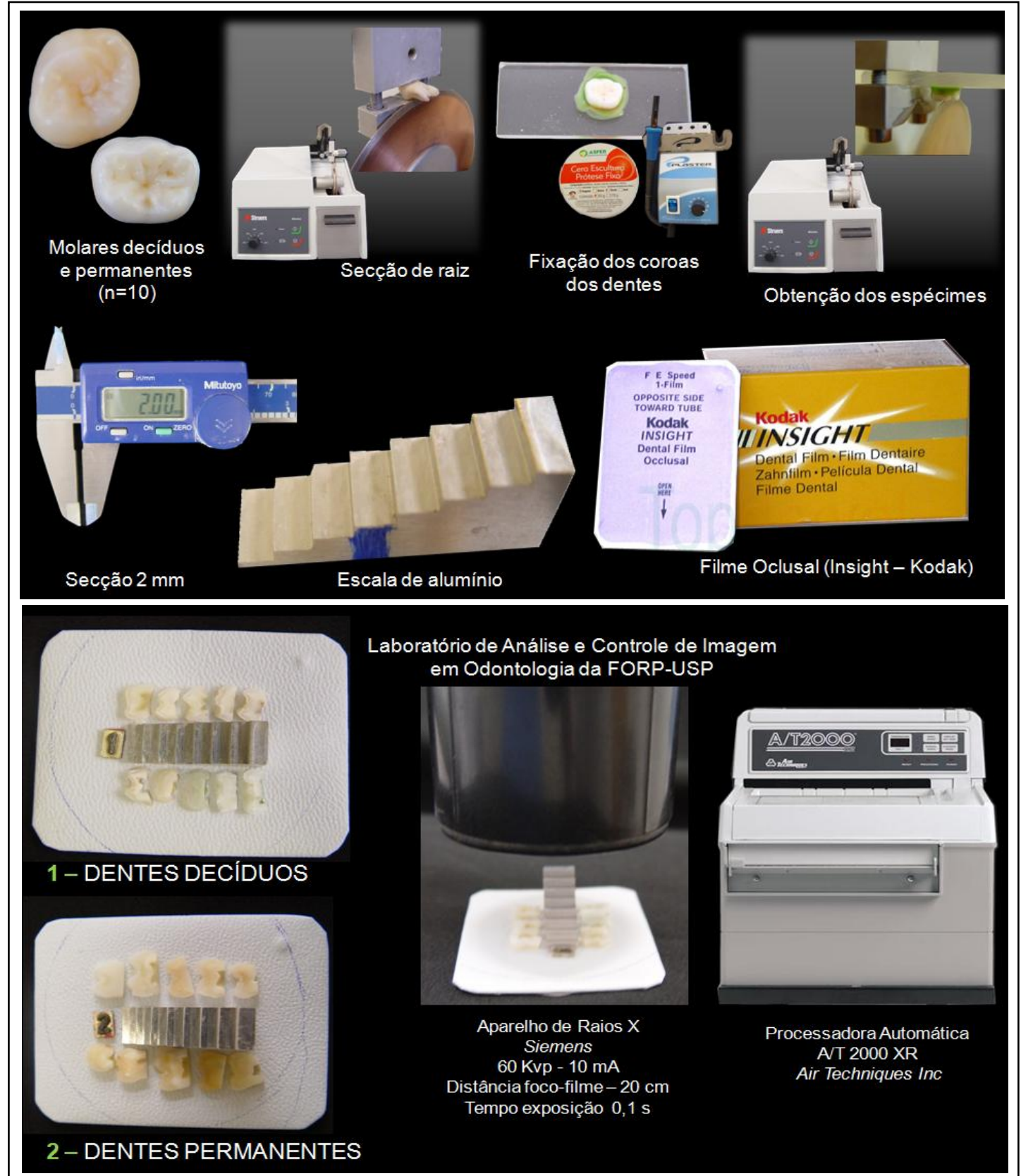
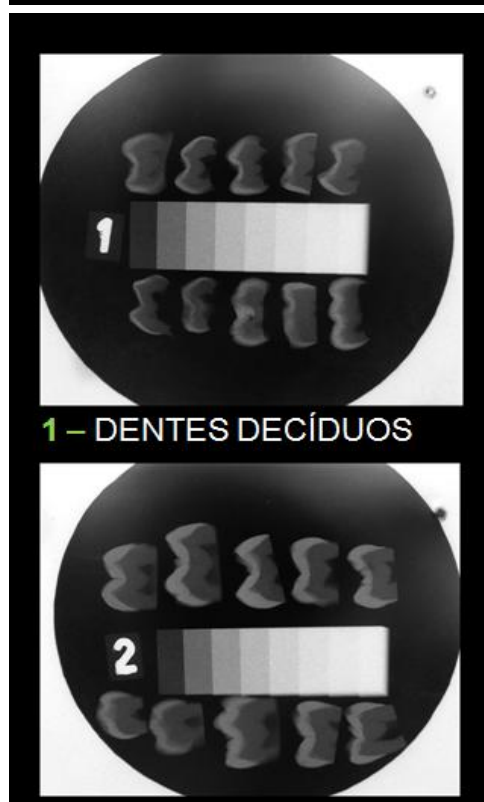

2 - DENTES PERMANENTES

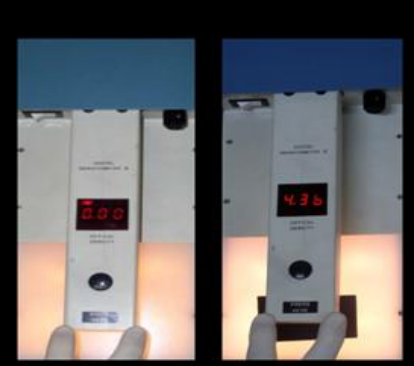

Fotodensitômetro Gafchromic

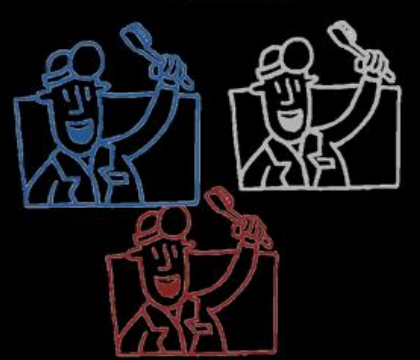

3 examinadores

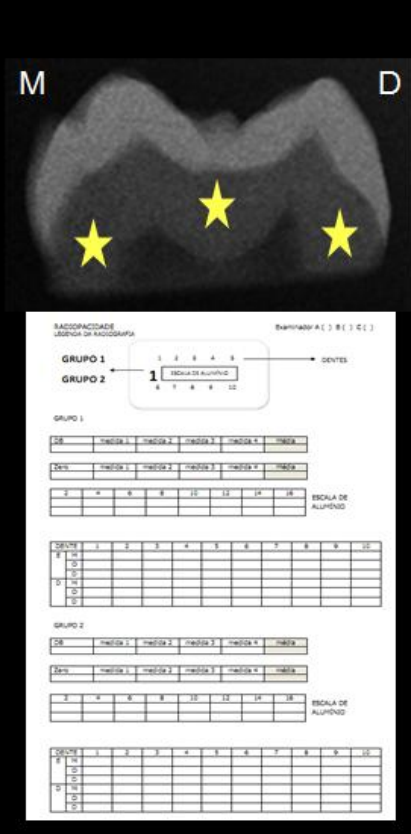

Figura 3 - Fluxograma da metodologia da análise de radiodensidade. 


\subsection{ReSistênCIA CoESiva (Ultimate TENSILE StRENGTH)}

A análise da resistência coesiva do substrato dentinário foi realizada por meio do teste de microtração. Foram selecionados 15 molares decíduos e 15 molares permanentes. A porção radicular, foi removida a $3 \mathrm{~mm}$ abaixo da junção amelocementária com um disco flexível diamantado (\#7015, KG Sorensen, Barueri, 06454-920, Brasil) montado em uma máquina de corte (Minitrom, Struers A/S, Copenhagen, DK-2610, Denmark).

As superfícies oclusais foram condicionadas com ácido fosfórico a 37\%, durante 30s, lavadas e secas com jatos de ar/água e em seguida, foi aplicado o sistema adesivo Single Bond (3M ESPE, St Paul, MN, USA), em duas camadas consecutivas e fotopolimerizadas durante 20s. Foram então, confeccionados "platôs" de resina compostas Z250 (3M ESPE, St Paul, MN, USA), em porções incrementais, fotopolimerizadas durante 20s cada, com a finalidade de aumentar a porção coronária para facilitar a confecção das seç̧ões. Considerando o tamanho reduzido dos molares decíduos, estes "platôs" de resina foram confeccionados na porção oclusal e na região correspondente à câmara pulpar destes dentes.

Os dentes foram fixados em uma base de acrílico (lâmina de plexiglass) com auxílio de cera para escultura (Kota Ind. e Com. Ltda, São Paulo, Brasil), aquecida em gotejador elétrico (Guelfi Equipamentos, Ribeirão Preto-SP, Brasil) e, por meio de um disco diamantado adaptado em máquina de corte, sob refrigeração, foram realizados cortes no sentido ocluso cervical, obtendo-se secções de $1 \mathrm{~mm}$ de espessura. A espessura foi controlada com o auxílio de um paquímetro universal com leitura eletrônica (Digimatic Caliper/code number 071-467B, Mitutoyo, Suzano, Brazil), com precisão de 0,01 mm.

Para cada dente, foram selecionadas duas seç̧ões, que foram distribuídas aleatoriamente em subgrupos, de acordo com a profundidade da dentina a ser testada:

- Dentina Superficial (S) - região da dentina próxima a junção amelodentinária

- Dentina Profunda $(P)$ - região da dentina próxima a câmara pulpar

O Quadro 1 descreve os grupos analisados. 
QUADRO 1- Quadro descritivo dos grupos testados

\begin{tabular}{|c|c|c|}
\hline Substrato & $\begin{array}{c}\text { Dentina Dentes Decíduos } \\
\text { Profundidade }\end{array}$ & $\begin{array}{c}\text { Dentina Dentes Permanente } \\
\text { (D) }\end{array}$ \\
\hline $\begin{array}{c}\text { Dentina Superficial } \\
\text { (S) }\end{array}$ & dS & DS \\
\hline $\begin{array}{c}\text { Dentina Profunda } \\
\text { (P) }\end{array}$ & dP & DP \\
\hline
\end{tabular}

Separadas as seç̧ões para cada subgrupo, foram confeccionados desgastes com o auxílio de uma ponta diamantada de granulação fina (3195 FF, KG Sorensen) montada em alta rotação, sob refrigeração, de maneira a obter áreas de $1 \mathrm{~mm}^{2}$.

Os espécimes, selecionados para o ensaio de microtração, tiveram suas áreas medidas e conferidas, utilizando-se um paquímetro universal com leitura eletrônica (Digimatic Caliper/code number 071-467B, Mitutoyo, Suzano, Brazil), com precisão de 0,01 $\mathrm{mm}$, sendo descartados aqueles que tivessem a área $<1,0$ e $>1,0 \mathrm{~mm}^{2}$. Em seguida, as secções foram fixadas individualmente pelas suas extremidades ao dispositivo para a realização do ensaio de microtração, com o auxílio de adesivo instantâneo Superbonder (GelHenkel Loctite Adesivos LTDA-São Paulo-Brasil), associado ao monômero da resina acrílica, posicionando-se o espécime paralelamente ao longo eixo da força de microtração. $O$ ensaio foi realizado em uma Máquina de Ensaio Universal (Modelo MEM 2000, EMIC Ltda, São José dos Pinhais, PR, Brazil), pertencente ao Laboratório Integrado de Pesquisa em Biocompatibilidade de Materiais do Departamento de Materiais Dentários e Prótese da Faculdade de Odontologia de Ribeirão Preto da Universidade de São Paulo, previamente ajustada para forças de microtração, com uma célula de carga de capacidade de $50 \mathrm{Kgf}$, a uma velocidade de $1 \mathrm{~mm} / \mathrm{min}$. No momento da fratura, o movimento foi imediatamente cessado e os dados foram coletados para cálculos posteriores. Os valores finais de resistência coesiva foram calculados, dividindo-se os valores de carga de ruptura, em Newton ( $\mathrm{N}$ ), pelas seç̧ões transversais dos espécimes, em $\mathrm{mm}^{2}$, sendo expressos em MPa. Foram desprezados os espécimes que não romperam na área da seç̧ão de $1 \mathrm{~mm}^{2}$ e aqueles que se soltaram durante o teste.

A metodologia deste experimento está representada na Figura 4 (A e B). 


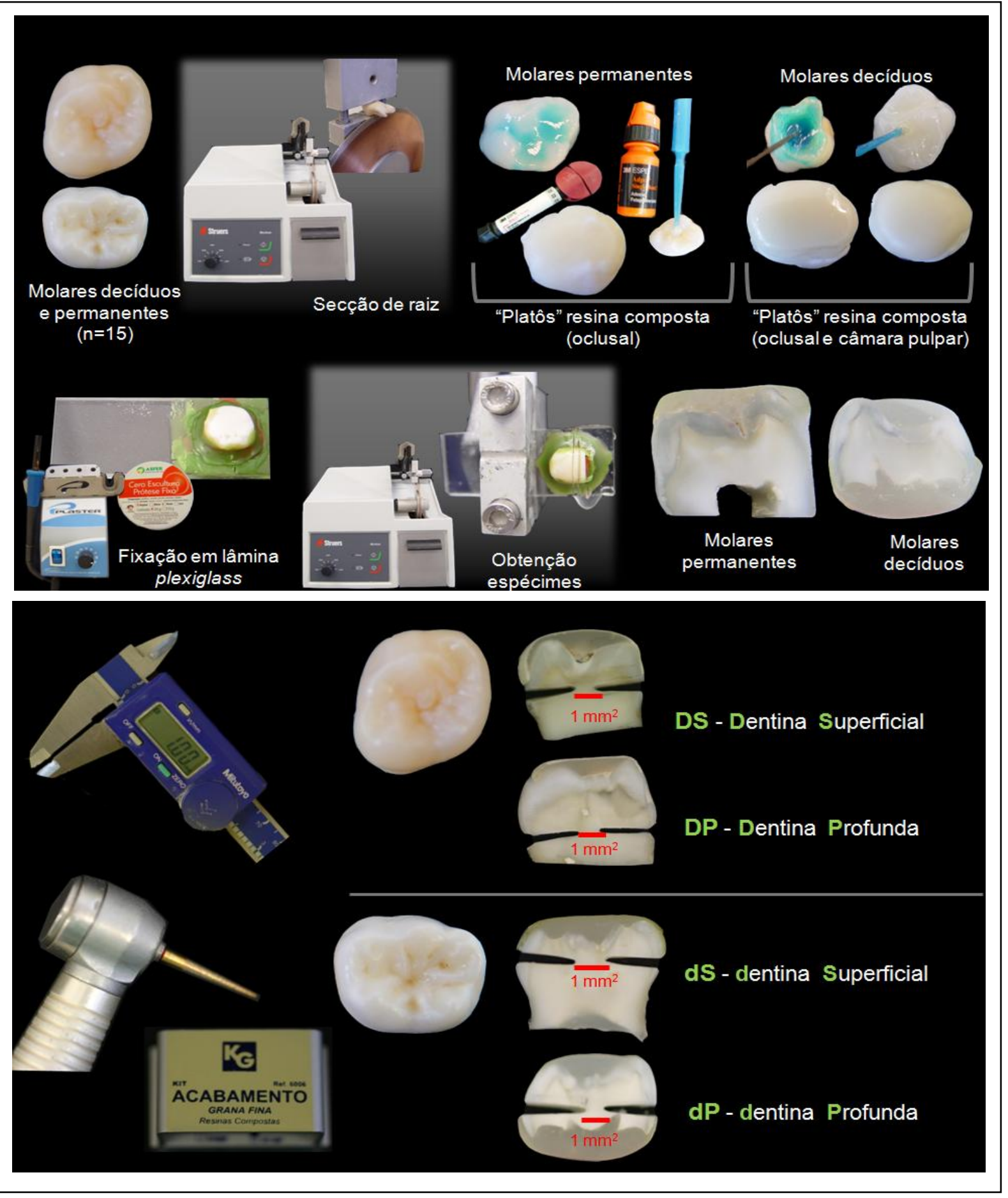

FIgURA 4A - Fluxograma da metodologia da análise de resistência coesiva. 

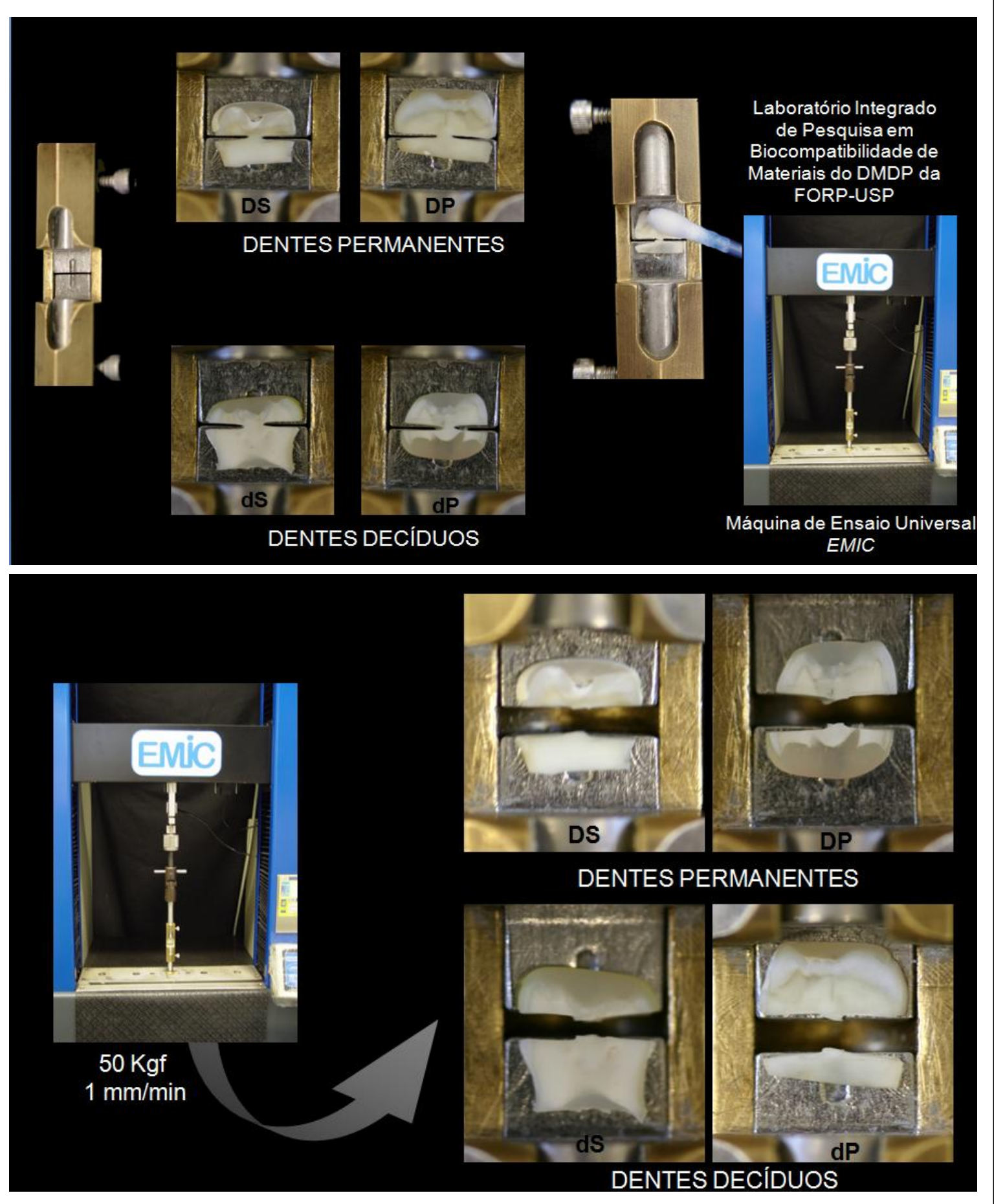

FiguRA 4B - Fluxograma da metodologia da análise de resistência coesiva. 


\subsection{MiCROfLUORESCÊNCIA DE RAIOS-X POR EnERGIA DISPERSIVA ( $\mu$ EDX)}

Para este teste, 10 molares decíduos e 10 molares permanentes foram levados a um equipamento de corte seriado (Minitom, Struers A/S, Copenhagen, DK-2610, Denmark), dotado de um disco diamantado (\#7015, KG Sorensen, Barueri, 06454-920, Brasil) refrigerado com água, e tiveram suas raízes seccionadas, $3 \mathrm{~mm}$ abaixo da junção amelocementária. As coroas foram fixadas em matrizes de resina acrílica, de forma que as superfícies vestibulares ficassem expostas. A seguir, os corpos de prova foram desgastados para expor a dentina, com lixas d'água aplicadas em ordem decrescente de abrasividade (\#600 a \#1200), em uma politriz (Politriz Universal Aropol 2 V, Arotec, Cotia, São Paulo, Brasil), sob refrigeração abundante, para em seguida serem polidos com disco de feltro embebido em pasta de alumina (Struers A/S, Copenhagen, DK-2610, Denmark) de granulações 0,3 $\mu \mathrm{m}$ e 0,05 $\mu \mathrm{m}$. Os espécimes foram então levados à cuba ultrassônica (Ultrasonic Clearner T-1449-D. Odontobrás Ind. e Com., 14075-060, Ribeirão Preto-SP Brasil) durante $5 \mathrm{~min}$.

As superfícies dentinárias foram submetidas à análise química por meio da Microfluorescência de Raios-X por Energia Dispersiva ( $\mu E D X)$ em um equipamento da marca Shimadzu modelo $\mu \mathrm{EDX}-1300$, pertencente ao Laboratório de Espectroscopia Vibracional Biomédica - LEVB - Universidade do Vale do Paraíba (UNIVAP). A superfície da amostra foi analisada longitudinalmente por dispersão de energia da radiação, proveniente de um tubo de $\mathrm{Rh}$, posicionado a $90^{\circ}$ e acoplado a um sistema computadorizado. A amostra foi irradiada com feixe de raios- $X$ de raios de $50 \mu \mathrm{m}$.

A análise quantitativa dos componentes Cálcio (Ca) e Fósforo $(P)$ foi realizada por varreduras em três pontos da superfície do espécime, com um tempo de $10 \mathrm{~s} /$ ponto. A voltagem do tubo foi de $15 \mathrm{kV}$ para a dentina, com um ajuste automático da corrente e um feixe de diâmetro de $50 \mu \mathrm{m}$. Em todas as medidas a contagem da radiação foi feita por um detector semicondutor de Si (Li) refrigerado por Nitrogênio líquido (Soares et al., 2009).

Para as medidas em dente, foi utilizado, como referência de calibração, o reagente de hidroxiapatita estequiométrica sintética, marca Sigma-Aldrich, grau de pureza 99,99\%. As condições analíticas foram baseadas no método dos parâmetros fundamentais. As variáveis para o cálculo da fórmula química foram estabelecidas para os pesos relativos de Cálcio (Ca) e Fósforo $(P)$, e o elemento Oxigênio $(O)$ foi utilizado como balanço químico. $O$ elemento 
Hidrogênio $(H)$ não foi considerado no balanço total de massa, uma vez que a sua massa é equivalente a $0,1 \%$ do peso total da hidroxiapatita (Soares et al., 2009).

A proporção entre os elementos químicos presentes nas amostras foi calculada pela razão dos pesos relativos determinados por leitura direta no equipamento. O software do equipamento fornece os dados a partir do cálculo de conversão da intensidade relativa das energias de transição dos raios- $X$, característicos dos elementos, para os respectivos teores em porcentagem de peso, no tempo de varredura determinado.

Após a realização do mapeamento em área, os dados correspondentes a cada amostra foram processados no software do sistema do EDX (PCMEDX Ver 1.04, Shimadzu Corp. Japão) e, em seguida, os valores da concentração em peso dos componentes Cálcio e Fósforo (máximo, mínimo) de cada mapeamento foram anotados e tabulados, sendo utilizado para a análise dos dados os valores médios de $\mathrm{Ca}$ e $\mathrm{P}$ e a proporção $\mathrm{Ca} / \mathrm{P}$.

A metodologia deste experimento está representada na Figura 5.

\subsection{ESPECTROSCOPIA RAMAN POR TRANSFORMADA DE FOURIER}

Para esta análise, 10 molares decíduos e 10 molares permanentes foram levados a um equipamento de corte seriado (Minitom, Struers A/S, Copenhagen, DK-2610, Denmark), dotado de um disco diamantado (\#7015, KG Sorensen, Barueri, 06454-920, Brasil) refrigerado com água, e tiveram suas raízes seccionadas, $3 \mathrm{~mm}$ abaixo da junção amelocementária. As coroas foram fixadas em matrizes de resina acrílica, de forma que as superfícies vestibulares ficassem expostas. A seguir, os corpos de prova foram desgastados para expor a dentina, com lixas d'água aplicadas em ordem decrescente de abrasividade (\#600 a \#1200), em uma politriz (Politriz Universal Aropol 2 V, Arotec, Cotia, São Paulo, Brasil), sob refrigeração abundante, para em seguida serem polidos com disco de feltro embebido em pasta de alumina (Struers A/S, Copenhagen, DK-2610, Denmark) de granulações $0,3 \mu \mathrm{m}$ e $0,05 \mu \mathrm{m}$. Os espécimes foram então levados à cuba ultrassônica (Ultrasonic Clearner T-1449-D. Odontobrás Ind. e Com., 14075-060, Ribeirão Preto-SP Brasil) durante $5 \mathrm{~min}$.

Foi utilizado o aparelho FT-Raman Spectrometer RFS 100/S - Bruker® Alemanha, instalado no Laboratório de Espectroscopia Vibracional Biomédica - LEVB - UNIVAP. A análise de um espectro Raman nos tecidos dentários fornece informações sobre a 
concentração relativa dos grupamentos Fosfato e Carbonato associados à molécula de hidroxiapatita, além do conteúdo orgânico presente nos substratos. As amostras foram posicionadas, uma a uma, no FT-Raman para coleta de espectros. O equipamento FT-Raman possui um laser de alta intensidade com comprimento de onda de 1064 nm, com potência máxima de 500 mW. Com o software instalado no FT-Raman Spectrometer RFS 100 (OPUS 4.2 Copyright $^{\odot}$ Bruker Optik GmHb 1997-2002) todos os parâmetros do equipamento, tais como: potência do laser, abertura do feixe, Transformada de Fourier, aquisição do espectro, gráfico em três dimensões, análises quantitativas e armazenamentos de dados, foram ajustados.

Os espectros de cada elemento dentário foram obtidos com um detector diodo refrigerado por nitrogênio $\left(\mathrm{N}_{2}\right)$ líquido. Uma fonte de laser $\mathrm{Nd}$ :YAG resfriado foi utilizado para vibração das moléculas Raman-ativas. A incidência máxima do laser na superfície do espécime foi de aproximadamente $70 \mathrm{~mW}$ e a resolução do espectro de $4 \mathrm{~cm}^{-1}$. Os dentes foram posicionados no espectrofotômetro, presos à matriz e a incidência do laser ocorreu na região mais central do espécime. As lentes IR354 coletaram a radiação espalhada até $180^{\circ}$ da superfície exposta. Os espectros de FT-Raman foram obtidos após 150 escaneamentos da superfície de cada amostra, com freqüência explorada variando de 100 a $3.500 \mathrm{~cm}^{-1}$, sendo que foram obtidos 5 espectros de 5 diferentes pontos de uma área circular de $2 \mathrm{~mm}$ de diâmetro delimitada previamente na superfície de cada espécime, com o auxílio de uma fita adesiva.

A avaliação das diferenças nas estruturas minerais e orgânicas foi executada comparando-se a relação entre as intensidades relativas dos picos em $\mathrm{CO}_{3}{ }^{2}-1070 \mathrm{~cm}^{-1}$ (Carbonato tipo B), $\mathrm{PO}_{4}{ }^{3}-430 \mathrm{~cm}^{-1}$ e $\mathrm{PO}_{4}{ }^{3}-590 \mathrm{~cm}^{-1}$ (Fosfato) e amida I-1670 cm $\mathrm{cm}^{-1}$, com o pico de $970 \mathrm{~cm}^{-1}$ (Fosfato). Este procedimento baseia-se na suposição de que a relação das intensidades dos modos de estiramento simétrico e anti-simétrico do íon fosfato não deve mudar (Wentrup-Byrne et al., 1997). Desta forma, os 5 espectros obtidos em um espécime foram comparados entre si quanto à intensidade dos referidos picos e foi obtido uma média de intensidade de cada pico em cada amostra.

A metodologia deste experimento está representada na Figura 6. 


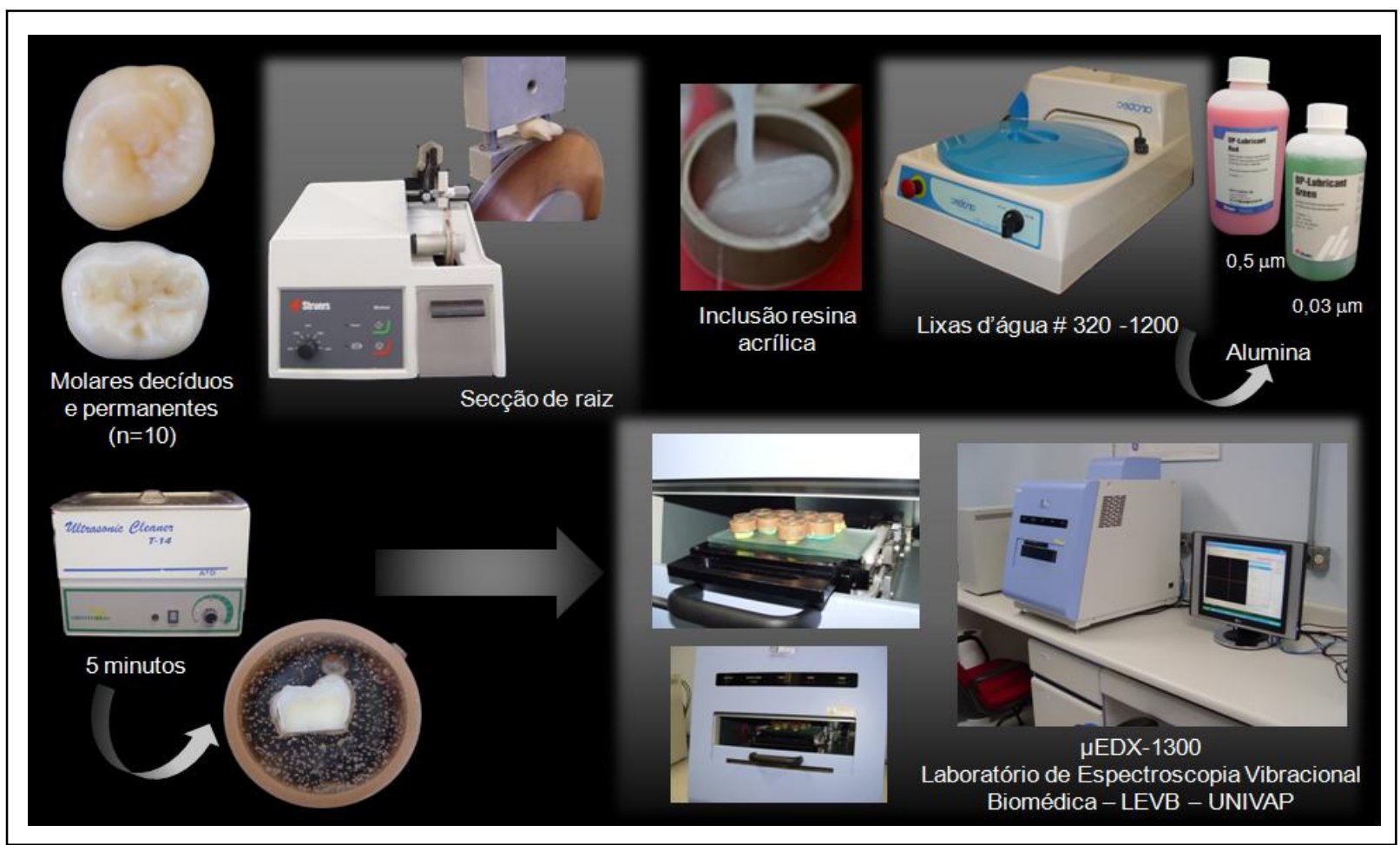

FigURA 5 - Fluxograma da metodologia da análise de mapeamento de superfície por Microfluorescência de Raios-X por Energia Dispersiva ( $\mu$ EDX).

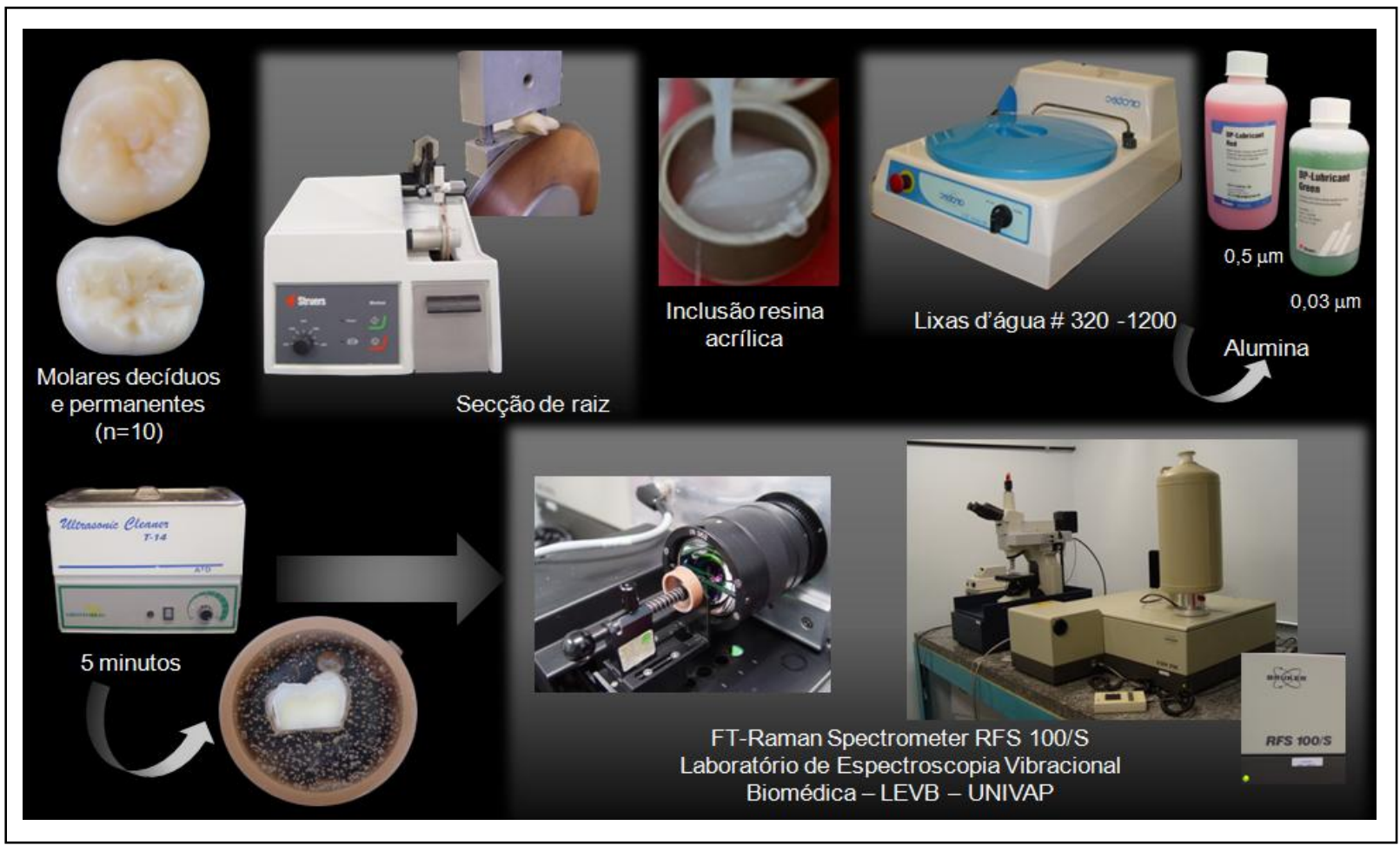

FiguRA 6 - Fluxograma da metodologia da análise de espectroscopia Raman por Transformada de Fourier. 


\subsection{ANÁLISE DOS DADOS}

Para a análise da Permeabilidade, foi realizada mensuração da área de penetração dos íons cobre ao longo da área total de dentina, obtendo-se valores de permeabilidade relativa da dentina em porcentagem ( $\% \mathrm{P})$.

Para a análise da Radiodensidade comparou-se a densidade óptica dos substratos.

Para a análise da Microtração analisou-se a resistência coesiva (ultimate tensile strength) da dentina de dentes decíduos e permanentes, em duas profundidades: dentina superficial (região da dentina próxima a junção amelodentinária) e profunda (região da dentina próxima a câmara pulpar), em valores expressos em MPa.

Para o mapeamento de superfície por Microfluorescência de raios-X por energia dispersiva foram avaliados os valores médios, em porcentagem (\%), de Cálcio (Ca) e Fósforo $(\mathrm{P})$, bem como a proporção da porcentagem em peso de $\mathrm{Ca} / \mathrm{P}$.

Para a Espectroscopia Raman por Transformada de Fourier foram analisadas as quantidades de $\mathrm{PO}_{4}{ }^{3}-430 \mathrm{~cm}^{-1}, \mathrm{PO}_{4}{ }^{3}-590 \mathrm{~cm}^{-1}, \mathrm{CO}_{3}{ }^{2}-1070 \mathrm{~cm}^{-1}$ e Amida I-1670 cm $\mathrm{cm}^{-1}$ na dentina de dentes decíduos e permanentes, expressas em unidades arbitrárias (ua).

Inicialmente, os dados foram analisados quanto a sua distribuição e homogeneidade. Nos resultados obtidos no teste de Microdureza, a distribuição não foi normal, portanto empregou-se o teste não paramétrico de Mann-Whitney. Para os demais, a distribuição apresentou-se normal e homogênea. Assim, os dados obtidos nas análises de Permeabilidade e Radiodensidade foram submetidos à Análise de Variância a um critério: tipo de substrato $(p<0,05)$. Para os resultados de Microtração, empregou-se Análise de Variância a dois critérios $(p<0,05)$ : tipo de substrato e profundidade. Para os dados de Microfluorescência de Raios-X por Energia Dispersiva e Espectroscopia Raman por Transformada de Fourier foi utilizado o teste t de Student. 
0
0
0
5
5
0
4
0 


\section{Resultados}

\subsection{Permeabilidade}

$\mathrm{Na}$ análise dos dados observou-se que na dentina dos dentes decíduos ocorreu uma maior profundidade de penetração de íons cobre em relação a área total de dentina avaliada em cada espécime, sendo diferente estatisticamente dos valores obtidos na dentina dos dentes permanentes $(p<0,05)$. Os valores médios e os desvios-padrão obtidos para cada substrato estão apresentados na Tabela 1.

TABELA 1 - Médias (\%) e desvios-padrão dos dados obtidos na análise de Permeabilidade

Tipo de Substrato

Dentina de Dentes Decíduos

Dentina de Dentes Permanentes

\section{Permeabilidade (\%)}

$$
33,88( \pm 7,76) \text { a }
$$

$$
22,86( \pm 8,02) \mathbf{b}
$$

Letras diferentes indicam diferença estatística $(p<0,05)$

A dentina dos dentes decíduos apresentou-se mais permeável que a dentina dos dentes permanentes (Figura 7).

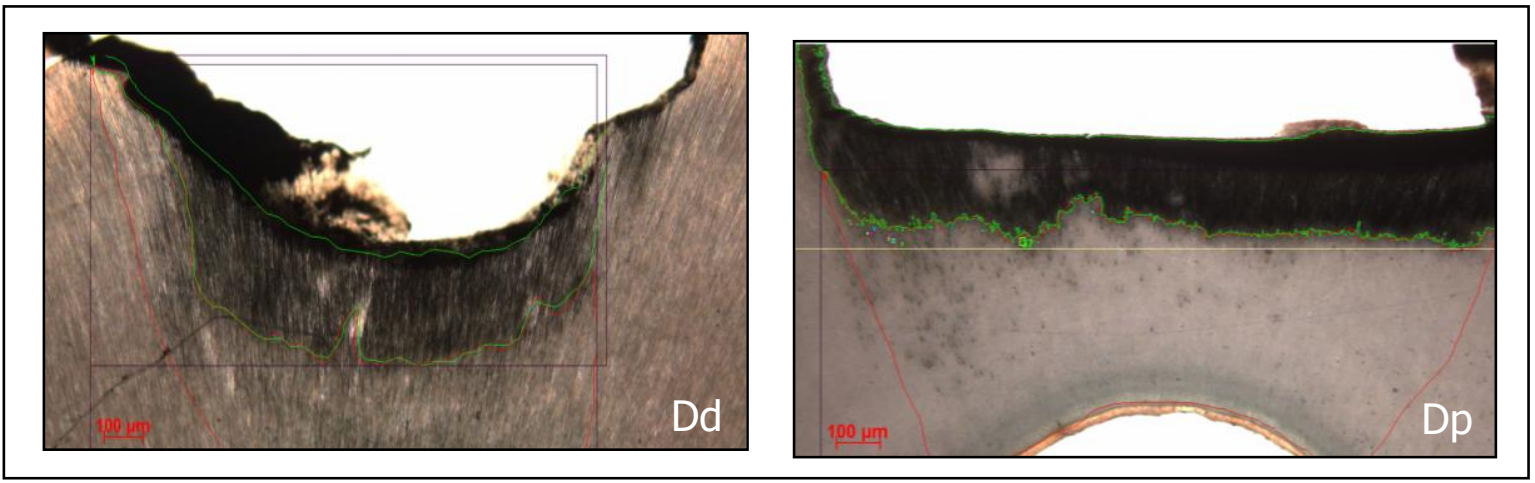

FIgURA 7 - Imagens digitais ilustrativas obtidas por Microscopia Óptica, representando as áreas de penetração dos íons cobre em relação à área total da dentina avaliada:

Dd) Dentina de dente decíduo

Dp) Dentina de dente permanente 


\subsection{MICRODUREZA}

$\mathrm{Na}$ análise dos dados de microdureza Knoop observou-se não haver diferença estatisticamente significante entre a dentina de dentes decíduos e permanentes $(p>0,05)$. Os valores médios e os desvios-padrão obtidos para cada substrato estão apresentados na Tabela 2.

TABELA 2 - Médias (KHN) e desvios-padrão dos dados obtidos na análise de Microdureza

\begin{tabular}{cc}
\hline Tipo de Substrato & Microdureza \\
\hline Dentina de Dentes Decíduos & $46,30( \pm 4,9)$ a \\
Dentina de Dentes Permanentes & $46,65( \pm 4,5)$ a \\
\hline
\end{tabular}

Letras iguais indicam similaridade estatística $(p>0,05)$.

A dentina de dentes decíduos apresentou valores de microdureza semelhantes aos valores obtidos na dentina de dentes permanentes.

\subsection{RADIODENSIDADE}

Em relação a radiodensidade da dentina observou-se que houve diferença estatisticamente significativa entre os substratos $(p<0,05)$. Pode-se observar na análise dos dados que os valores de densidade óptica da dentina de dentes permanentes foi estatisticamente superior aos valores obtidos na dentina de dentes decíduos. Os valores médios e os desvios-padrão obtidos para cada substrato estão apresentados na Tabela 3.

TABELA 3 - Médias e desvios-padrão dos dados obtidos na análise de densidade óptica

\begin{tabular}{cc}
\hline Tipo de Substrato & Densidade Óptica \\
\hline Dentina de Dentes Decíduos & $1,85( \pm 0,02) \mathbf{a}$ \\
Dentina de Dentes Permanentes & $1,88( \pm 0,03) \mathbf{b}$ \\
\hline
\end{tabular}

Letras diferentes indicam diferença estatística $(p<0,05)$.

A dentina de dentes decíduos apresentou valores de densidade óptica menores que a dentina de dentes permanentes. 


\subsection{ResistênCia Coesiva (Ultimate Tensile StRength)}

$\mathrm{Na}$ análise dos dados, observou-se que para o fator substrato, a dentina do dente decíduo apresentou menores valores, sendo estatisticamente diferentes dos valores obtidos na dentina de dentes permanentes $(p<0,05)$. No entanto, para o fator profundidade, não houve diferença estatisticamente significante nos resultados da força coesiva obtidos nos substratos avaliados independentemente $(p>0,05)$. Os valores médios e os desvios-padrão obtidos para cada substrato estão apresentados na Tabela 4.

TABELA 4 - Médias (MPa) e desvios-padrão dos dados obtidos na análise da Resistência Coesiva

Tipo de Substrato

Resistência Coesiva

Superficial

Profunda

\begin{tabular}{ccc}
\hline Dentina de Dentes Decíduos & $42,75( \pm 3,5)$ B & $41,64( \pm 3,06)$ b \\
Dentina de Dentes Permanentes & $46,94( \pm 3,37)$ A & $45,59( \pm 3,72)$ a \\
\hline
\end{tabular}

Letras diferentes indicam diferenças estatisticamente significante nas colunas $(p<0,05)$.

A dentina de dentes decíduos apresentou menores valores de resistência coesiva que a dentina de dentes permanentes. Porém, não houve diferença na dentina superficial, próxima à junção amelodentinária, quando comparada à dentina profunda, região próxima à polpa, nos substratos avaliados independentemente.

\subsection{MicroflUORESCÊNCIA DE RAIOS-X POR ENERGIA DISPERSIVA ( $\mu$ EDX)}

$\mathrm{Na}$ análise química pode-se observar diferença estatisticamente significativa na porcentagem de íons Cálcio $(\mathrm{Ca})$ entre a dentina de dentes permanentes e de dentes decíduos $(p<0,05)$. No entanto, não houve diferença significativa para porcentagem de íons Fósforo $(P)$ entre os substratos $(p>0,05)$. Na relação $\mathrm{Ca} / \mathrm{P}$ em peso, observou-se valores estatisticamente superiores para a dentina de dentes permanentes $(p<0,05)$. Os valores médios e os desvios-padrão obtidos para cada substrato estão apresentados na Tabela 5. 
TABela 5 - Médias (\%) e desvios-padrão de Cálcio (Ca) e Fósforo (P) e proporção Ca/P, em peso (\%),obtidos no mapeamento de superfície por microfluorescência de raios$\mathrm{X}$ por energia dispersiva

\begin{tabular}{cccc}
\hline Tipo de Substrato & Ca & P & Ca/P \\
\hline Dentina de Dentes Decíduos & $27,50( \pm 1,0)$ b & $15,37( \pm 0,4)$ A & $1,79( \pm 0,03) \bullet$ \\
\hline Dentina de Dentes Permanentes & $28,61( \pm 0,4)$ a & $15,62( \pm 0,3)$ A & $1,83( \pm 0,03) \diamond$
\end{tabular}

Letras e símbolos diferentes indicam diferença estatisticamente significante nas colunas.

A dentina de dentes decíduos apresentou porcentagens de Cálcio menores que a dentina de dentes permanentes. Assim como a proporção Ca/P, em peso (\%). No entanto, houve similaridade entre a porcentagem de Fósforo $(P)$ entre a dentina de dentes decíduos e permanentes (Figura $8 A$ e Figura $8 B$ ).

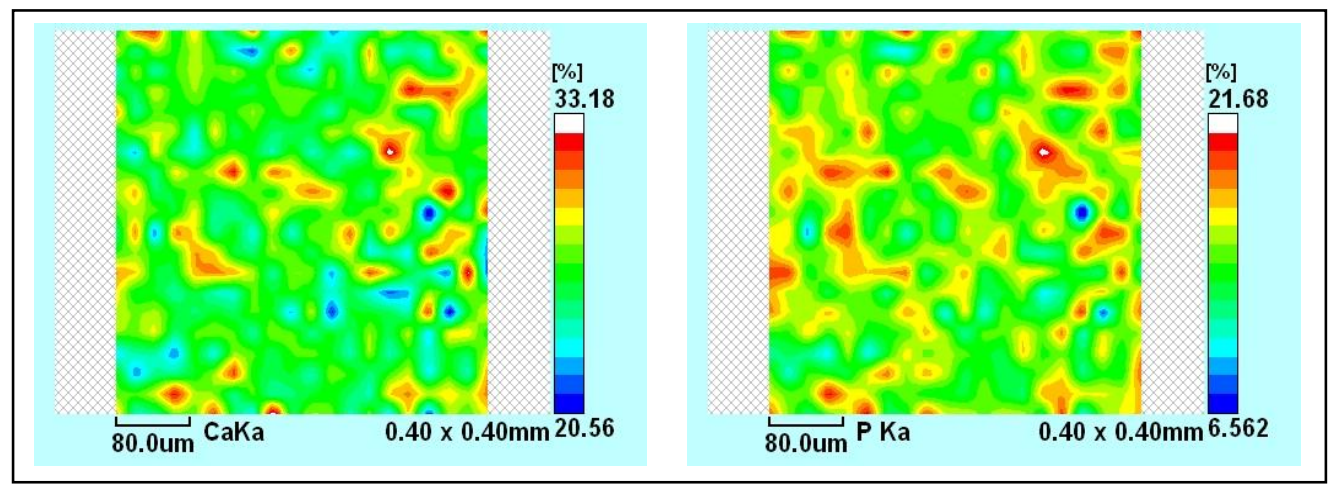

FigurA 8A - Imagem ilustrativa de uma amostra da dentina de dente decíduo analisado, demonstrando os valores (máximo e mínimo) da concentração em peso (\%) dos íons Cálcio (Ca) e Fósforo (P) processadas no software do sistema do EDX, PCMEDX Versão 1.04.

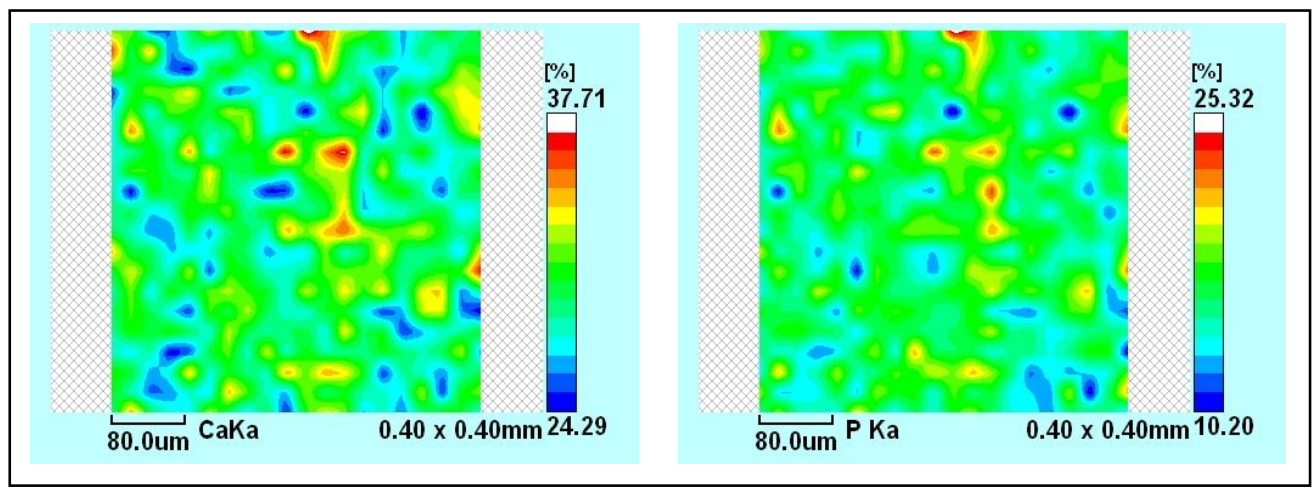

FiguRA 8B - Imagem ilustrativa de uma amostra da dentina de dente permanente analisado, demonstrando os valores (máximo e mínimo) da concentração em peso (\%) dos íons Cálcio (Ca) e Fósforo (P) processadas no software do sistema do EDX, PCMEDX Versão 1.04. 


\subsection{ESPECTROSCOPIA RAMAN POR TRANSFORMADA DE FOURIER}

A análise espectral mostrou duas partes características: primeiramente, uma região que se estende de 300 a $1100 \mathrm{~cm}^{-1}$, características de grupamentos Fosfato e Carbonato, representativa da fase mineral da dentina e, uma outra região que mostra os modos vibracionais dos grupos orgânicos na região de 1200 a $2000 \mathrm{~cm}^{-1}$. O espectro Raman foi dissociado em bandas para melhor observação dos picos (Figura 9).

$\mathrm{Na}$ análise dos dados obtidos, não foram observadas diferenças significativas para os valores de médios dos picos de $\mathrm{PO}_{4}{ }^{3}-430, \mathrm{PO}_{4}{ }^{3}-590$ e Amida I entre a dentina de dentes decíduos e permanentes ( $p>0,05$ ). No entanto, houve diferença estatisticamente significante na banda de $\mathrm{CO}_{3}{ }^{2}$ nos substratos avaliados, tendo a dentina dos dentes decíduos apresentado os maiores valores $(p<0,05)$. Os valores médios (obtidos em unidades arbitrárias) e os desvios-padrão das áreas dos espectros da dentina de dentes decíduos e permanentes estão descritos na Tabela 6.

TABela 6 - Valores médios (ua) e desvios-padrão dos dados obtidos na análise de Espectrometria Raman por Transformada de Fourier

\begin{tabular}{ccccc}
\hline Tipo de Substrato & $\mathbf{P O}_{\mathbf{4}}{ }^{\mathbf{3}}-\mathbf{4 3 0}$ & $\mathbf{P O}_{\mathbf{4}}{ }^{\mathbf{3}}-\mathbf{5 9 0}$ & $\mathbf{C O}_{\mathbf{3}}{ }^{\mathbf{2}}$ & Amida I \\
\hline $\begin{array}{c}\text { Dentina de Dentes } \\
\text { Decíduos }\end{array}$ & 3,49 & 3,50 & 3,81 & 3,12 \\
$( \pm 0,04) \mathbf{a}$ & $( \pm 0,05) \mathbf{A}$ & $( \pm 0,1) \diamond$ & $( \pm 0,1) *$ \\
$\begin{array}{c}\text { Dentina de Dentes } \\
\text { Permanentes }\end{array}$ & 3,51 & 3,51 & 3,72 & 3,02 \\
& $( \pm 0,05) \mathbf{a}$ & $( \pm 0,06) \mathbf{A}$ & $( \pm 0,08) \bullet$ & $( \pm 0,1) *$
\end{tabular}

Letras e símbolos diferentes indicam diferença estatisticamente significante nas colunas.

A dentina de dentes decíduos apresentou conteúdo orgânico e Fosfato semelhantes aos valores observados na dentina de dentes permanentes. No entanto, o conteúdo de Carbonato foi maior na dentina de dentes decíduos. 


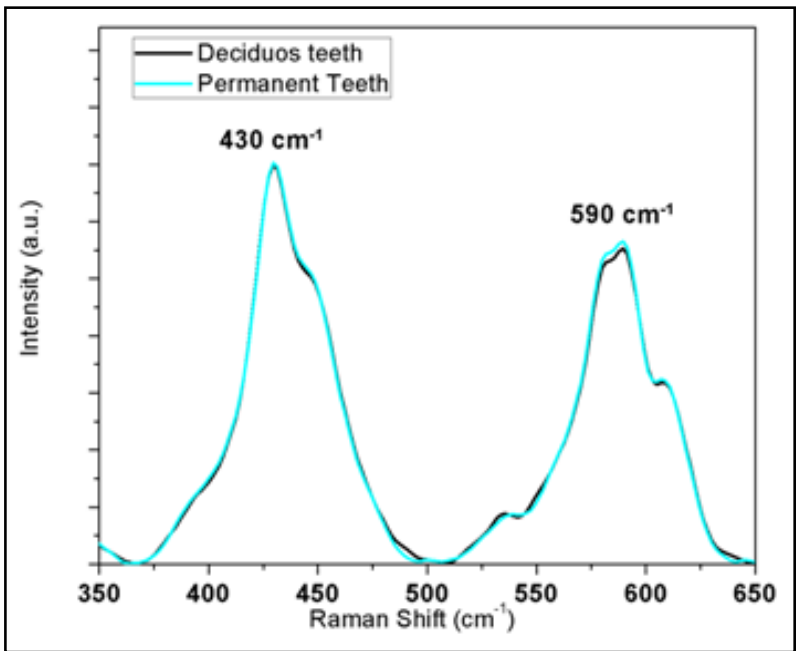

Média do conteúdo de Fosfato:

$-\mathrm{PO}_{4}{ }^{3}-430 \mathrm{~cm}^{-1}$

$-\mathrm{PO}_{4}{ }^{3}-590 \mathrm{~cm}^{-1}$

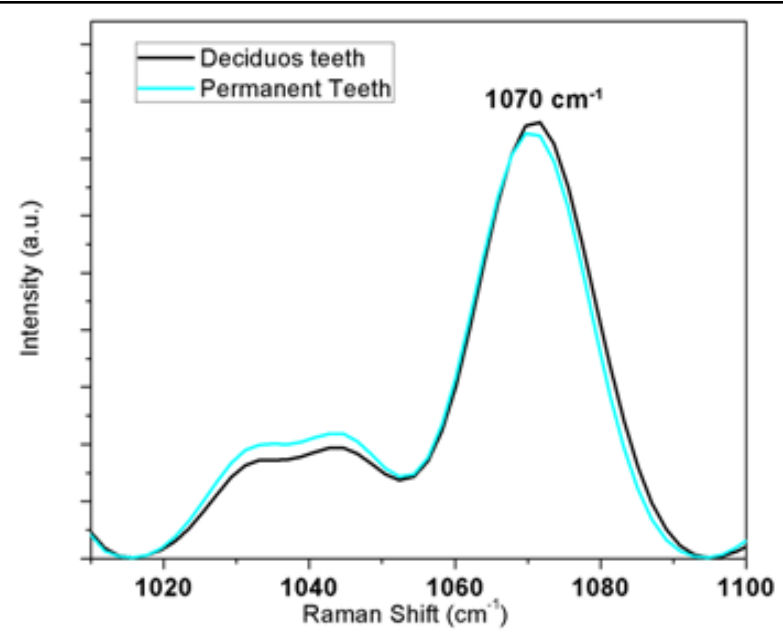

Média do conteúdo de Carbonato:

$-\mathrm{CO}_{3}^{2}-1070 \mathrm{~cm}^{-1}$

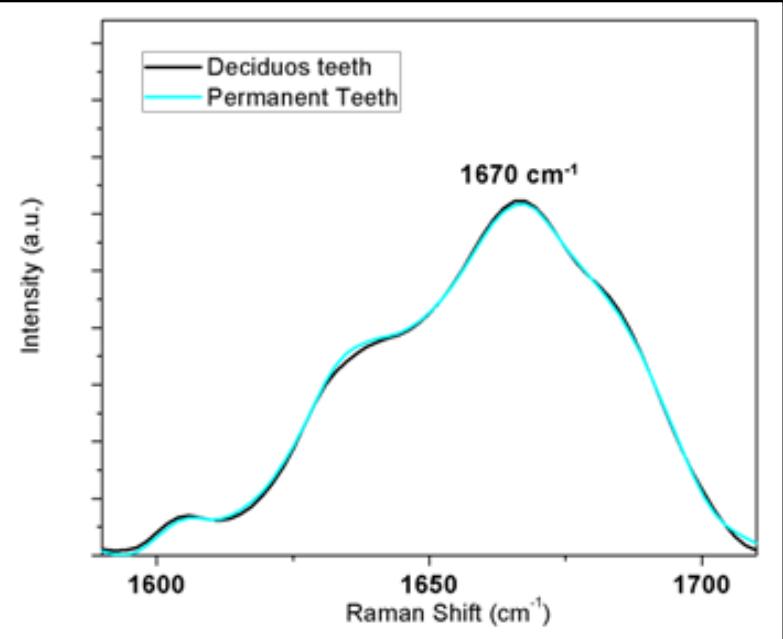

Média do conteúdo de Amida I:

- amida I-1670 $\mathrm{cm}^{-1}$

FiguRA 9 - Relação entre as médias dos espectros Raman da dentina de dentes decíduos (linha preta) e dentes permanentes (linha azul). 


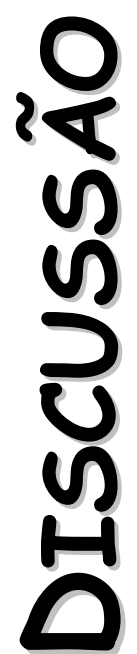




\section{DISCUSSÃO}

\subsection{ANÁlise dA Permeabilidade}

A configuração anatômica tubular da dentina sugere que este substrato seja altamente permeável. Cortes perpendiculares ao longo eixo destes túbulos, revelam um aspecto microscópico semelhante ao de uma peneira. Porém, a dentina deve ser entendida como um tecido mineralizado altamente dinâmico e sua permeabilidade está na dependência de alguns fatores como o número, diâmetro e extensão dos túbulos, espessura do tecido dentinário, dos movimentos dos fluidos no interior dos túbulos de acordo com a concentração osmótica e hidrostática, da presença da smear layer e da temperatura (Pashley et al., 1983; Maroli et al., 1992; Koutsi et al., 1994).

O estudo da permeabilidade da dentina é importante, na medida em que esta propriedade está diretamente relacionada à sensibilidade dolorosa, à possibilidade de microinfiltração na interface dente/material restaurador e à difusão no substrato de produtos tóxicos até tecido pulpar. Assim, quanto maior a permeabilidade dentinária, maior o contato do fluido tubular com o material odontológico (capeador, forrador, restaurador), o que poderá ocasionar a solubilização dos componentes destes materiais, favorecendo a microinfiltração desta restauração e a difusão de componentes tóxicos, levando a injúrias ao tecido pulpar e promovendo, desta forma, o insucesso do procedimento restaurador (Lanza et al., 2009). Neste sentido, a permeabilidade da dentina é essencial para a fisiologia e para os padrões de reação do complexo dentino-pulpar (Mjör, 2009).

Desta forma, a análise da permeabilidade se constitui em um método eficaz para a avaliação de procedimentos restauradores e preventivos (Pashley et al., 1993; Abou Hashied et al., 1998; Kazemi et al., 1999). Neste estudo, aplicou-se a utilização de corantes para a avaliação da permeabilidade, observando-se que a dentina dos dentes decíduos mostrou-se mais permeável em comparação a dentina do dente permanente.

A maioria dos estudos é realizada somente em dentes permanentes, ou somente em dentes decíduos, entretanto, é evidente que dentes decíduos e permanentes possuem características próprias que podem influenciar nas propriedades do tecido dentário, como na permeabilidade, e devem ser comparados utilizando os mesmos métodos, como no presente estudo. 
A velocidade de formação e mineralização são maiores e o ciclo de vitalidade é menor no tecido dentinário do dente decíduo, possivelmente gerando uma dentina menos densa, com túbulos mais irregulares e apresentando metade da espessura observada nos dentes permanentes (Menezes-Oliveira, 2009).

Koutsi et al. (1994) observaram que a condutibilidade hidráulica da dentina dos dentes decíduos é menor comparada aos dentes permanentes, concluindo que a dentina dos dentes decíduos é menos permeável que a dentina dos dentes permanentes. Estes autores atribuíram tais resultados a menor densidade e diâmetro dos túbulos observados na dentina dos dentes decíduos. Outros autores (Hirayama et al., 1985; Schilke et al. 2000) também relataram uma menor densidade e diâmetro dos túbulos na dentina dos dentes decíduos comparativamente a dentina do dente permanente.

Portanto, poderíamos explicar os resultados do presente estudo relacionando aos resultados da análise química dos substratos. A dentina do dente decíduo apresentou menor conteúdo de Cálcio e Fósforo e maior conteúdo de Carbonato, o que implicaria em uma estrutura com um maior grau de solubilidade. Menezes-Oliveira (2009) demonstrou que a quantidade de túbulos dentinários foi ligeiramente maior na dentina do dente permanente em comparação ao dente decíduo, podendo-se inferir que a quantidade de dentina intertubular no dente decíduo seria maior, como observado por Costa et al. (2002). Ainda, Subba Reddy e Chowdhary (2010) verificaram que a dentina de dentes decíduos apresentou a direção dos túbulos dentinários com trajeto sinuoso (curvatura em "s") em 26,7\% das amostras, e a maioria (73,3\%), túbulos com trajetos retos. Nos dentes permanentes, em $100 \%$ das amostras, foi observado o trajeto sinuoso dos túbulos. Portanto, a maior permeabilidade encontrada na dentina do dente decíduo poderia ser explicada em função da diferença na qualidade e quantidade da dentina intertubular e na disposição e trajeto dos túbulos nestes tecidos.

Aliando-se a estes dados, o fato da espessura da dentina do dente decíduo ser a metade da espessura do dente permanente (Menezes-Oliveira, 2009), a maior permeabilidade da dentina do dente decíduo comparativamente a do dente permanente seria mais preocupante. Isto porque a espessura da dentina é um dos fatores mais importantes que afetam a permeabilidade, pois esta age como uma excelente barreira contra injúrias patológicas e iatrogênicas (Hatton et al., 1994; Cetingüç et al., 2006). 


\subsection{ANÁLISE DA MICRODUREZA}

A maior quantidade de tecido mineralizado da estrutura dentária é representada pela dentina. O conhecimento de suas propriedades mecânicas é essencial tanto para prever as alterações estruturais propiciadas pelos processos cariosos e de respostas aos estímulos da cavidade bucal, como para definir a melhor escolha do procedimento restaurador, desde a confecção da cavidade à escolha do material restaurador.

Desta forma, conhecendo-se que existem diferenças entre o substrato do dente decíduo e do dente permanente e que os estudos relacionados às propriedades mecânicas da dentina do dente decíduo comparativamente ao dente permanente são escassos, torna-se relevante a análise da microdureza, neste estudo, para a comparação entre os substratos. Alguns autores (Mahoney et al., 2000; Angker et al., 2003; Angker et al., 2004; Hosoya et al., 2007) avaliaram as propriedades mecânicas da dentina do dente decíduo e seu conteúdo mineral, porém, não compararam ao grupo constituído por dentes permanentes.

A avaliação das propriedades mecânicas da dentina por meio do teste de microdureza tem sido amplamente utilizada, uma vez que esta pode estar relacionada com outras propriedades mecânicas como resistência à fratura, módulo de elasticidade e força de adesão (Currey e Brear, 1990 ; Kinney et al., 2003).

A microdureza é definida com a resistência à deformação permanente de uma superfície quando uma carga é aplicada por um endentador (aço, tungstênio ou diamante). A medida da dureza se dá pela relação entre unidade de força pela unidade de área deformada (Kinney et al. 1996; Kinney et al., 2003).

A microdureza Knoop, aplicada neste estudo, tem sido amplamente utilizada nos substratos dentários, pois sua endentação permite medidas mais precisas mesmo em áreas onde as marcas são rasas, devido ao fato de sua ponta de penetração possuir uma diagonal longa (Kinney et al., 2003).

Na presente investigação não houve diferença nos valores de microdureza Knoop comparando-se a dentina de dentes decíduos e dentes permanentes, concordando com os resultados de Borges et al. (2007).

Alguns autores relataram que a microdureza dentinária depende da concentração mineral presente no tecido ou pela menor mineralização da matriz da dentina intertubular (Featherstone et al., 1983; Kinney et al., 1996). De acordo com os resultados apresentados, 
a dentina do dente decíduo apresentou uma porcentagem em peso da relação $\mathrm{Ca} / \mathrm{P}$ menor comparativamente ao dente permanente.

Porém, Roy e Basu (2008) reportaram que a variação na microdureza depende parcialmente da concentação mineral do tecido, mas também de outras características microestruturais locais. Pashley et al. (1985), correlacionaram inversamente a microdureza da dentina com a densidade tubular, observando que o aumento da densidade tubular em regiões próximas a polpa corresponderam à uma redução dos valores de microdureza. Low et al (2008) relataram a umidade do tecido como fator de alteração da microdureza. Ainda, Ryou et al. (2011) investigaram a importância da microestrutura e da composição química da dentina de dentes permanentes em diferentes profundidades nas propriedades mecânicas deste substrato. Os autores observaram que a dentina profunda, próxima à câmara pulpar, apresentou um menor conteúdo de colágeno em comparação à dentina superficial ou periférica, o que justificaria os menores valores de resistência mecânica.

Assim, em virtude das microendentações serem grandes o suficiente para englobarem a dentina tubular, peritubular e intertubular, os valores de microdureza possivelmente estão na dependência de outras características do tecido como a densidade, diâmetro e orientação dos túbulos, da matriz de colágeno e do padrão de mineralização do substrato.

Neste contexto, de acordo com outros autores (Koutsi et al., 1994; Costa et al., 2002; Menezes-Oliveira, 2009) a densidade tubular e o diâmetro dos túbulos dentinários são menores na dentina do dente decíduo. Ainda, devido ao curto período de permanência na cavidade bucal do dente decíduo, este seria mais suscetível às alterações advindas das respostas às agressões ou aos mecanismos fisiológicos do envelhecimento, como a obliteração dos túbulos dentinários, mesmo tendo sua resposta biológica reduzida com o início da rizólise (Araújo et al., 1995; Mjör, 2009).

Um trabalho de Hosoya e Marshall (2005) avaliou por meio do teste de nano dureza a dentina de dentes decíduos e permanentes, concluindo que menores valores foram encontrados para o dente decíduo. Talvez, se o teste de nanoedentação, no qual avalia-se somente a dentina intertubular fosse realizado, os resultados deste estudo seriam diferentes.

As propriedades mecânicas da dentina do dente decíduo comparativamente ao dente permanente são pouco estudadas. A determinação e comparação destas propriedades sob as mesmas condições de preparo e teste é importante visto que até mesmo a forma de armazenagem pode provocar alterações mecânicas (Habelitz et al., 2002). O conhecimento destas características é importante para entender como estes tecidos reagem sob condições 
clínicas, bem como prever o comportamento da interface dente/restauração na cavidade bucal.

\subsection{ANÁLISE DA RADIODENSIDADE}

Um dos objetivos principais da Odontologia é a promoção e manutenção da saúde bucal. Para tal finalidade, o correto diagnóstico da doença cárie e o controle preciso da utilização dos materiais capeadores, forradores e restauradores se tornam mandatórios. Neste sentido, um importante método auxiliar da Odontologia é a utilização da imagem radiográfica. Os materiais odontológicos deveriam apresentar-se radiograficamente com tonalidades das nuances que permitissem diferenciá-los das estruturas anatômicas adjacentes e de lesões de cárie (Espelid et al., 1991; Hara et al., 2001).

A radiopacidade é uma propriedade importante dos materiais odontológicos e tecidos biológicos mineralizados e pode ser definida como o inverso da densidade óptica da imagem radiográfica. A densidade radiográfica pode ser descrita como o grau de enegrecimento da radiografia concluída. Quanto maior o grau de escurecimento, maior a densidade e menor a quantidade de luz que atravessará a radiografia quando colocada na frente de um negatoscópio ou de um foco de luz (Souza et al., 2010).

A densidade óptica é o logarítimo da razão da intensidade de luz incidente pela intensidade de luz transmitida por meio do filme radiográfico. Esta não depende somente da metodologia usada como tipo de filme, parâmetros de exposição e processamento radiográficos, mas também, das propriedades de absorção de radiação do próprio substrato (Watts e McCabe, 1999).

Desta maneira, no presente estudo objetivou-se padronizar as outras variáveis que poderiam interferir na densidade óptica. Assim, as diferenças existentes seriam resultantes apenas das características químicas e microestruturais de cada tecido avaliado.

Alguns autores concluíram que, para um ótimo contraste, um material restaurador que apresentasse uma radiopacidade maior ou igual a do esmalte do dente permanente seria ideal para o diagnóstico de lesões de cárie nas radiografias (Espelid et al., 1991; Chan et al., 1999). Neste contexto, conforme a especificação número 27 da Associação Dentária Americana (1981) os materiais deveriam apresentar radiopacidade equivalente a $1 \mathrm{~mm}$ de alumínio, que é aproximadamente a radiopacidade da dentina do dente permanente. 
Concordando, as diretrizes da Organização Internacional para Padronização - 4049 (1985) determinaram que um material odontológico resinoso deveria apresentar uma radiopacidade no mínimo igual a do alumínio puro, na mesma espessura.

Como descrito, os materiais odontológicos são fabricados e avaliados, no que diz respeito a radiopacidade, baseados nas estruturas dos dentes permanentes ou ao alumínio. Sabendo-se que as características dos substratos interferem nos valores de densidade óptica e que a literatura específica evidencia diferenças morfológicas, na composição química e estrutural entre dentes decíduos e dentes permanentes, justifica-se o conhecimento dos valores de densidade óptica da dentina do dente decíduo para que sejam desenvolvidos materiais específicos para este tecido, visando um correto diagnóstico de alterações na cavidade bucal.

Em concordância com outros autores (Van Dijken et al., 1989; Devito et al., 2004), na presente investigação o valor médio da densidade óptica da dentina dos dentes permanentes foi aproximadamente equivalente a do alumínio na mesma espessura.

Neste trabalho, a densidade óptica média da dentina dos dentes permanentes foi maior que a dos dentes decíduos. Baseando-se nos resultados da literatura e da presente investigação, as quantidades de Cálcio e Fósforo são maiores na dentina do dente permanente (Hirayama, 1990, Menezes-Oliveira, 2009).

Portanto, a suposição que quanto menor a quantidade mineral, maior a densidade óptica não foi confirmada no presente trabalho.

Neste estudo, a quantidade de Carbonato tipo B (banda de $1070 \mathrm{~cm}^{-1} /$ substituição do Carbonato pelo fosfato na molécula de hidroxiapatita) foi maior na dentina dos dentes decíduos no teste de Espectroscopia Raman por Transformada de Fourier. Uma vez que o íon Carbonato é menor que o íon fosfato, este fato diminuiria o tamanho molecular dos cristais de hidroxiapatita e tornaria a estrutura menos cristalina (LeGeros et al., 1999; Leventouri et al., 2009). Ainda, de acordo com outros autores (Koutsi et al., 1994; Costa et al., 2002; Menezes-Oliveira, 2009) a densidade tubular e o diâmetro dos túbulos dentinários são menores na dentina do dente decíduo. Adicionalmente, o dente decíduo apresenta um desenvolvimento rápido e ciclo biológico reduzido em comparação do dente permanente, o que poderia acelerar e propiciar as alterações estruturais físicas e químicas (como alterações na disposição e configuração geométrica dos cristais), decorrentes da permanência do mesmo na cavidade bucal (Borges et al., 2007). Estes fatos poderiam, em parte, explicar a maior radiopacidade observada na dentina dos dentes decíduos neste estudo.

Para assegurar um contraste adequado da radiografia, os espécimes utilizados apresentaram um espessura de $2 \mathrm{~mm}$ (Watts e McCabe, 1999). Este fator é importante para 
um diagnóstico diferencial, pois com uma espessura menor, provavelmente não seria possível distinguir as três estruturas dentárias mineralizadas na imagem radiográfica (esmalte/dentina/cemento).

A metodologia utilizada nesta investigação foi similar a de outros estudos que avaliaram a radiopacidade de materiais (Gürdal e Akdeniz, 1998; Devito et al., 2004; Souza et al., 2010).

O questionamento sobre o quão radiopaco um material deveria apresentar-se para um correto e preciso diagnóstico tem sido avaliado por vários autores (Devito et al., 2004; Ergücü et al., 2010). No entanto, não se tem o conhecimento de artigos que investigaram a radiopacidade dos materiais odontológicos em comparação as estruturas dentárias dos dentes decíduos. Portanto, baseado nos resultados do presente trabalho, materiais mais específicos para serem utilizados na dentina do dente decíduo deveriam ser desenvolvidos.

\subsection{ANÁLISE dA ReSistênCIA Coesiva (Ultimate TENSILE STRENGTH)}

Para minimizar o desgaste dentário funcional na cavidade bucal, o dente é constituído por tecidos mineralizados que apresentam propriedades físicas baseadas em sua composição e estrutura micromorfológica. Portanto, a força de resistência a tração da dentina se relaciona com a composição e distribuição das estruturas no tecido, dentina tubular, intertubular e peritububular (Carvalho et al., 2001; Staninec et al., 2003).

Tem sido verificado, em testes de resistência da interface adesiva, um aumento das fraturas coesivas no substrato dentinário, em função da evolução de alguns sistemas adesivos atuais (Pashley et al., 1995; De Munck et al., 2002). Em parte isto pode ser atribuído à composição da dentina, que contribui para os valores reportados de resistência da união dos materiais aos tecidos, uma vez que durante o ensaio a carga aplicada não se concentra somente na interface dissipando-se também pelo tecido (Van Noort et al., 1991).

Portanto, o conhecimento da resistência a tração dos tecidos que compõem a estrutura dental é importante para que protocolos e materiais específicos para cada substrato sejam instituídos. Neste contexto, a literatura existente, na maioria das vezes, utiliza dentes permanentes. Ainda, não se tem o conhecimento de estudos comparando a dentina do dente decíduo e a do dente permanente em um mesmo trabalho.

Desde sua introdução (Sano et al., 1994) o ensaio de microtração tem sido amplamente utilizado para a análise da resistência mecânica da interface adesiva entre os 
materiais odontológicos e as estruturas dentárias, bem como na análise da resistência a tração do próprio tecido e dos materiais em si (Giannini et al., 2004; Lührs et al., 2011). As maiores vantagens do teste de microtração são a maior uniformidade da distribuição das tensões na área de teste e a possibilidade de avaliar a resistência mecânica em áreas menores com maior fidelidade dos valores obtidos (Pashley et al., 1995; Pashley et al., 1999) Trabalhos têm demonstrado que a força de resistência coesiva da dentina depende de alguns fatores como a orientação e densidade dos túbulos, bem como a orientação das fibras colágenas do tecido (Carvalho et al. 2001; Inoue et al., 2003; Miguez et al., 2004).

No presente estudo, a força de tração foi aplicada paralelamente a orientação dos túbulos dentinários. Alguns autores (Carvalho et al., 2001; Inoue et al., 2003; Bedran-deCastro et al., 2004) relataram que os valores da resistência coesiva da dentina foram maiores quando a força foi aplicada perpendicularmente a orientação dos túbulos dentinários, pois como demonstrado por Miguez et al. (2004) a maioria das fibras colágenas estão dispostas perpendicularmente ou obliquamente a direção dos túbulos. Portanto, a metodologia aplicada neste estudo foi assim delineada, porque como valores de resistência coesiva, nos testes de microtração, são iguais ou superiores aos obtidos quando a força é aplicada paralelamente aos túbulos, este método poderia indicar os valores limítrofes para que ocorra fratura coesiva no substrato.

No presente estudo, a dentina de dentes decíduos apresentou menores valores de resistência coesiva que os obtidos na dentina de dentes permanentes. Porém, não houve diferença nos valores verificados na dentina superficial, próxima à junção amelodentinária, daqueles verificados na dentina profunda, região próxima à polpa, nos dois substratos, quando analisados isoladamente. Carvalho et al. (2001) e Inoue et al. (2003) relataram que a maior densidade de túbulos dentinários pode estar relacionada a menores valores de resistência coesiva da dentina. De acordo com trabalhos na literatura (Koutsi et al., 1994; Costa et al., 2002; Menezes-Oliveira, 2009) a densidade tubular e o diâmetro dos túbulos dentinários são menores na dentina do dente decíduo. Desta forma, pode-se explicar os resultados da presente investigação especulando-se que exista uma diferença nas ligações entre as fibras colágenas da dentina do dente decíduo e do dente permanente. Neste contexto, Bedran-Russo et al., 2007 observaram que a utilização de agentes exógenos para aumentar as ligações cruzadas colagênicas na dentina desmineralizada aumentou os valores de resistência a tração deste tecido. Miguez et al. (2004) relataram que a matriz de colágeno na dentina contribui significativamente na força de resistência a tração do tecido. Sano et al., 
(1994) concluíram que a matriz de colágeno da dentina desmineralizada contribuiu em $30 \%$ nos valores da resistência mecânica a tração do substrato.

De acordo com Subba Reddy e Chowdhary (2010) a dentina de dentes decíduos apresentou uma diferença na direção dos túbulos em comparação ao dente permanente, sendo que em $100 \%$ das amostras o trajeto foi sinuoso para o dente permanente comparativamente a $73,3 \%$ de trajeto reto para o dente decíduo. Assim, pode-se especular que no presente estudo a força aplicada na dentina do dente decíduo foi na maioria dos espécimes paralelamente a direção dos túbulos, e na dentina dos dentes permanentes esta força pode ter sido aplicada também obliquamente e até perpendicularmente à direção tubular, o que aumentaria os valores da resistência coesiva.

Ainda, diante das diferenças entre a dentina do dente decíduo e permanente observados neste trabalho quanto ao padrão de mineralização, que implicaria em um maior grau de solubilidade do tecido dentinário do dente decíduo, podemos especular que este fator também possa interferir nas propriedades mecânicas do tecido dentinário.

As dimensões reduzidas dos espécimes, principalmente para os dentes decíduos podem ter sido responsáveis pelos valores semelhantes nas diferentes profundidades da dentina, diferentemente ao reportado por Hosoya et al., 2005. Este fato, e na tentativa de se aplicar a força paralelamente à direção dos túbulos (descartando as áreas entre os cornos pulpares), as áreas dos testes ficaram relativamente próximas.

Os valores observados na presente investigação foram de aproximadamente $42 \mathrm{MPa}$ para a dentina dos dentes decíduos e $46 \mathrm{MPa}$ para a dentina dos dentes permanentes, em uma área de $1 \mathrm{~mm}^{2}$. Resultados semelhantes foram reportados por Giannini et al. (2004), que observaram valores de $61,6( \pm 16,3), 48,7( \pm 16,7)$ e 33,9 $( \pm 8,0) \mathrm{MPa}$, respectivamente para a região de dentina superficial, média e profunda de dentes permanentes aplicando a força paralelamente a orientação tubular com uma área de teste de 0,5 $\mathrm{mm}^{2}$. Ainda, Nishitani et al., (2005), descreveram valor médio de 42,74 MPa quando avaliando a dentina de dentes permanentes na direção paralela aos túbulos, em uma área de 0,5 $\mathrm{mm}^{2}$. Em relação ao dente decíduo, Hosoya et al. (2005) analisando uma área de teste de $1,5 \mathrm{~mm}^{2}$ na região central da dentina de molares decíduos um valor médio de 46,5 $( \pm 15,7) \mathrm{MPa}$.

Resultados diferentes foram relatados por Sano et al. (1994) que observaram valores de resistência a microtração da dentina coronária do dente permanente $(0,5 \times 0,5 \mathrm{~mm})$ de $104 \pm 27,6 \mathrm{MPa}$ para a carga aplicada perpendicularmente à direção dos túbulos. Inoue et al. (2003), relataram valores de $99,8 \pm 27,9 \mathrm{MPa}(0,5 \times 0,5 \mathrm{~mm})$ para a carga aplicada 
perpendicularmente e de 77,6 $\pm 24,7 \mathrm{MPa}(0,5 \times 0,5 \mathrm{~mm})$ para a carga aplicada paralelamente a direção dos túbulos dentinários da dentina de dentes permanentes.

As diferenças nos valores de resistência a microtração da dentina reportados na literatura podem ser explicados em função de diferenças na metodologia como a área do teste e a direção de aplicação da força e grupo de dentes utilizados (Inoue et al., 2003; Bedran de Castro et al., 2004; Nishitani et al., 2005). Estudos mais específicos em relação à matriz de colágeno comparativamente entre a dentina dos dentes decíduos são necessários.

Baseando-se nos resultados deste estudo, os valores médios encontrados por Almeida (2011) de microtração da interface adesiva entre a dentina do dente decíduo e o sistema adesivo Clearfil SE Bond de 42,72 ( $\pm 10,20)$ MPa estaria no limite para a ocorrência de fraturas coesivas no tecido. Assim, materiais e protocolos adesivos específicos para cada substrato deveriam ser instituídos.

\subsection{ANÁlise dA Microfluorescência de RAIOS-X POR ENERgIA Dispersiva E ESPECTROSCOPIA RAMAN POR TRANSFORMADA DE FOURIER}

As técnicas de Microfluorescência de Raios-X e Espectroscopia Raman por Transformada de Fourier constituem ferramentas úteis, não destrutivas que permitem, respectivamente, uma análise qualitativa e quantitativa dos elementos presentes na amostra e a determinação da composição química molecular dos substratos.

A determinação da composição química dos tecidos dentários é importante, visto que a qualidade do substrato influenciará a determinação dos protocolos adesivos e preventivos adequados. Neste sentido, conhecendo-se que existem diferenças estruturais entre a dentina de dentes decíduos e permanentes e que as análises destas diferenças na literatura em um mesmo trabalho são escassas, torna-se essencial o conhecimento do conteúdo mineral e orgânico destes tecidos.

Na presente investigação observou-se que a porcentagem em peso da relação $\mathrm{Ca} / \mathrm{P}$ foi menor e os valores do pico $1070 \mathrm{~cm}^{-1}$ relacionado ao $\mathrm{CO}_{3}^{2}$ (Carbonato tipo $\mathrm{B}$ ) foram maiores na dentina do dente decíduo em comparação a dentina do dente permanente.

O íon Carbonato pode ocupar os mesmos sítios dos íons hidroxila (Carbonato tipo A) e dos íons Fosfato (Carbonato tipo B) na molécula de hidroxiapatita (Sønju Clasen e 
Ruyter,1997; LeGeros et al., 1999). A inclusão do Carbonato altera a estabilidade química e a estrutura física da hidroxiapatita. Leventouri et al. (2009) observaram que ocorreu uma diminuição na dimensão da estrutura da hidroxipatita com o envelhecimento do dente permanente, associando este resultado com o aumento da quantidade de Carbonato, que por sua vez está relacionado a uma diminuição da cristalinidade e a um aumento da solubilidade do tecido.

Em relação ao conteúdo de Cálcio e Fósforo, pode-se expecular que os resultados deste estudo tenham ocorrido em função do tempo reduzido para a maturação dos tecidos dentários no dente decíduo. Em tal contexto, Hirayama (1990) relatou que as concentrações de Cálcio e Fósforo na dentina de dentes decíduos são menores do que em dentes permanentes. Em outro estudo, Hirayama et al. (1985) não observaram diferença no conteúdo de Cálcio e Fósforo na dentina inter e peritubular, entre dentes decíduos e permanentes. Lakomaa e Rytömaa (1977) também não observaram diferenças no conteúdo de Cálcio e Fósforo entre o esmalte e a dentina de dentes permanentes em comparação com dentes decíduos.

Em relação aos resultados do conteúdo orgânico, neste trabalho não houve diferença significante entre dois substratos avaliados. Resultados semelhantes foram descritos por Borges et al., (2007). Ager et al. (2006) observaram que o pico relacionado a amida I aumentou com o envelhecimento dentário. Neste contexto, estudos com metodologias mais específicas para a avaliação da matriz de colágeno presente nestes dois substratos necessitam ser desenvolvidos.

Como visto anteriormente, devido ao ciclo biológico reduzido e a velocidade de formação maior no dente decíduo, este substrato seria mais suscetível às alterações advindas das respostas as agressões ou aos mecanismos fisiológicos do envelhecimento, mesmo tendo sua resposta biológica reduzida com o início da rizólise (Araújo et al., 1995; Mjör, 2009). Adicionalmente, porque a dentina não sofre remodelação, os efeitos do envelhecimento seriam mais aparentes neste tecido comparativamente aos outros tecidos dentários mineralizados (Kinney et al., 2005).

Desta forma, os resultados das análises químicas do presente estudo poderiam explicar os comportamentos diferentes da dentina dos dentes decíduos e permanentes frente aos desafios ácidos e procedimentos adesivos. A dentina do dente decíduo parece desmineralizar mais rapidamente comparativamente a dentina do dente permanente. Mejàre e Stenlund (2000) relataram que a incidência de lesões cariosas na dentina de dentes permanentes foi de 20,5 lesões/100 superfícies dentárias ao ano em comparação à taxa de 34,6 para a dentina de dentes decíduos. Ainda, alguns autores observaram que a resistência 
da interface adesiva da dentina de dentes decíduos utilizando diferentes sistemas adesivos apresentou valores inferiores aos observados nos dentes permanentes (Burrow et al., 2002; Senawongse et al., 2004; Courson et al., 2005), enquanto Nör et al. (1997) inferiram que a dentina do dente decíduo parece ser mais reativa ao condicionamento ácido. Desta forma, tem-se sugerido uma diminuição no tempo de condicionamento ácido na dentina do dente decíduo, para que uma camada híbrida mais adequada seja formada (Shashikiran et al., 2002). Neste sentido, os novos sistemas adesivos dentinários autocondicionantes podem ser uma opção viável para a dentina dos dentes decíduos. Almeida (2010), relatou valores de microtração de 42,72 $\mathrm{MPa}$, utilizando uma adesivo autocondicionante. Porém, estudos relacionados à longevidade desta resistência adesiva deverão ser reconduzidos. Ainda, sabendo que os íons fluoretos modificam a estrutura da hidroxipapatita de forma contrária a do Carbonato (diminuindo a solubilidade e aumentando a cristalinidade) (Leventouri et al., 2009; Aoba, 1997), protocolos preventivos específicos para o dente decíduo deveriam ser determinados.

Os trabalhos existentes, em relação ao estudo comparativo da dentina de dentes decíduos e permanentes quanto a análise das propriedades químicas e físicas, são escassos. Esse fato, aliado às diferenças nas metodologias empregadas nos estudos, definiu-se como um obstáculo e um desafio para que os resultados da presente investigação pudessem ser comparados aos da literatura. Algumas peculiaridades próprias da dentina do dente decíduo, observadas no presente trabalho, sugerem possíveis condutas clínicas, distintas daquelas adotadas nos dentes permanentes. Em face disso, outros estudos se fazem necessários para o entendimento mais preciso da estrutura do dente decíduo, fornecendo maior embasamento para a conduta clínica, que assim terá o respaldo biológico necessário. 


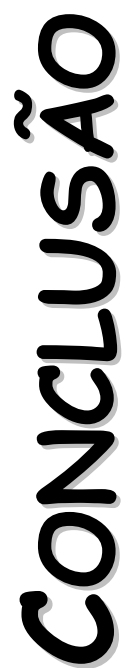




\section{CONCLUSÃo}

Considerando-se as limitações de um estudo in vitro, pode-se concluir que:

- Em relação às propriedades físicas, a dentina de dentes decíduos apresentou maior permeabilidade, menor radiodensidade, bem como uma menor resistência coesiva do substrato quando comparado à dentina de dentes permanentes. Entretanto, a microdureza foi semelhante nos dois tecidos dentinários.

- Para as propriedades químicas avaliadas, constatou-se que a dentina de dentes decíduos apresentou menor conteúdo em peso de Cálcio (\%) e da proporção $\mathrm{Ca} / \mathrm{P}(\%)$ e, maior porcentagem em conteúdo de Carbonato. No entanto, os valores dos conteúdos de Fósforo, Fosfato e orgânico, representado pela Amida I, apresentarem-se semelhantes. 


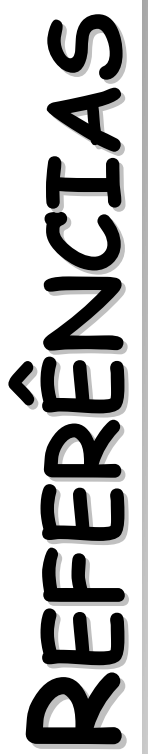




\section{REFERÊNCIAS}

Abou Hashieh I, Franquin JC, Cosset A, Dejou J, Camps J. Relationship between dentin hydraulic conductance and the cytotoxicity of four dentin bonding resins in vitro. J Dent $1998 ; 26: 473-7$

Ager JW, Nalla RK, Balooch G, Kim G, Pugach M, Habelitz S, Marshall GW, Kinney $\mathrm{JH}$,Ritchie RO. On the Increasing Fragility of Human Teeth With Age: A Deep-UV Resonance Raman Study. J Bone and Mineral Res 2006;21:1879-1887.

Almeida CG. Microtração de sistemas adesivos autocondicionantes em dentina desmineralizada de dentes decíduos irradiada com laser de Er:YAG: Avaliação in vitro [dissertação]. Ribeirão Preto: Faculdade de Odontologia de Ribeirão Preto, Universidade de São Paulo; 2011.

American Dental Association Council on Dental Materials, Instruments and Equipments. The desirability of using radiopaque plastics in dentistry: A status report. J Am Dent Assoc 1981;102:347-349.

Angker L, Swain MV, Kilpatrick N. Micro-mechanical characterisation of the properties of primary tooth dentine. J Dent. 2003;31:261-7.

Angker L, Nockolds C, Swain MV, Kilpatrick N. Quantitative analysis of the mineral content of sound and carious primary dentine using BSE imaging. Arch Oral Biol 2004;49:99-107.

Aoba T. The effect of fluoride on apatite structure and growth. Crit Rev Oral Biol Med 1997;8:136-153.

Araújo FB, Moraes FF, Fossati ACM. A estrutura da dentina do dente decíduo e sua importância clínica. Rev Bras Odont 1995;52:37-43.

Bedran-de-Castro AK, Pereira PN, Thompson JY. Influence of load cycling and tubule orientation on ultimate tensile strength of dentin. J Adhes Dent 2004;6:191-194.

Bedran-Russo AK, Pereira PN, Duarte WR, Drummond JL, Yamauchi M. Application of crosslinkers to dentin collagen enhances the ultimate tensile strength. J Biomed Mater Res B Appl Biomater 2007;80:268-72. 
Borges AFB, Bitar RA, Kantovitz KR, Correr AB, Martin AA, Puppin-Rontani RM. New perspectives about molecular arrangement of primary and permanent dentin. Applied Surface Sci 2007;254:1498-1505.

Burrow MF, Nopnakeepong U, Phrukkanon S. A comparison of microtensile bond strengths of several dentin bonding systems to primary and permanent dentin. Dent Mater 2002;18:23945.

Carvalho RM, Fernandes CAO, Villanueva R, Wang L, Pashley DH. Tensile strength of human dentin as a function of tubule orientation and density. J Adhesive Dent 2001;3:309-314, 2001.

Causton BE. Improved bonding of composite restorative to dentine. A study in vitro of the use of a commercial halogenated phosphate ester. Br Dent J 1984;156:93-5.

Cetingüç $A$, Olmez $S$, Vural N. HEMA diffusion from dentin bonding agents through various dentin thicknesses in primary molars. Am J Dent. 2006;19:231-5.

Chan DCN, Titus HW, Chung KH, Dixon H, Wellinghoff ST, Rawls HR. Radiopacity of tantalum oxide nanoparticle filled resins. Dent Mater 1999;15:219-222.

Costa LR, Watanabe IS, Kronka MC, Silva MC. Structure and microstructure of coronary dentin in non-erupted human deciduous incisor teeth. Braz Dent J. 2002;13:170-4.

Courson F, Bouter D, Ruse ND, Degrange M. Bond strengths of nine current dentine adhesive systems to primary and permanent teeth. J Oral Rehabil 2005;32:296-303.

Currey JD, Brear K. Hardness, Young's modulus and yield stress in mammalian mineralized tissues J Mater Sci Mat Med 1990;1:14-20.

De Munck J, Van Meerbeek B, Yudhira R, Lambrechts P, Vanherle G. Micro-tensile bond strength of two adhesives to Erbium:YAG-lased vs. bur-cut enamel and dentin. Eur J Oral Sci 2002;110:322-9.

Devito KL, Ortega AI, Haiter-Neto F. Radiopacity of calcium hydroxide cement compared with human tooth structure. J Appl Oral Sci 2004;12:290-3.

Ergücü $Z$, Türkün LS, Onem E, Güneri P. Comparative radiopacity of six flowable resin composites. Oper Dent 2010;35:436-40. 
Espelid I, Tveit AB, Erickson RL, Keck SC, Glasspoole EA. Radiopacity of restorations and detection of secondary caries. Dent Mater 1991;7:114-7.

Featherstone JD, ten Cate JM, Shariati M, Arends J. Comparison of artificial caries-like lesions by quantitative microradiography and microhardness profiles. Caries Res. 1983;17:385-91.

Garberoglio R, Brännström M. Scanning electron microscopic investigation of human dentinal tubules. Arch Oral Biol 1976;21:355-62.

Giannini M, Carvalho RM, Martins LR, Dias CT, Pashley DH. The influence of tubule density and area of solid dentin on bond strength of two adhesive systems to dentin. J Adhes Dent 2001;3:315-24.

Giannini M, Soares C], de Carvalho RM. Ultimate tensile strength of tooth structures. Dent Mater 2004;20:322-9.

Gürdal P, Akdeniz BG. Comparison of two methods for radiometric evaluation of resin-based restorative materials. Dentomaxillofac Radiol 1998;27:236-9.

Habelitz S, Marshall GW Jr, Balooch M, Marshall SJ. Nanoindentation and storage of teeth. J Biomech 2002;35:995-8.

Hara AT, Serra MC, Haiter-Neto F, Rodrigues AL Jr. Radiopacity of esthetic restorative materials compared with human tooth structure. Am J Dent 2001;14:383-6.

Hatton JF, Pashley DH, Shunk J, Stewart GP. In vitro and in vivo measurement of remaining dentin thickness. J Endod 1994;20:580-4.

Hirayama A, Yamada M, Miake K. An electron microscopy study on dentinal tubules of human deciduous teeth. Shikwa Gakuho 1986;86:1021-31.

Hirayama A. Experimental analytical electron microscopic studies on the quantitative analysis of elemental concentrations in biological thin specimens and its application to dental science. Shikwa Gakuho 1990;90:1019-36.

Hirayama A, Yamada M, Miake K. Analytical electron microscopy study on dentinal tubules of human deciduous teeth. J Dent Res 1985;64:64-743.

Hosoya Y, Marshall GW. The nano-hardness and elastic modulus of sound deciduous canine dentin and young premolar dentin--preliminary study. J Mater Sci Mater Med 2005;16:1-8. 
Hosoya Y, Tay FR. Hardness, elasticity and ultrastructure of bonded sound and cariesaffected primary tooth dentin. J Biomedical Mater Research Part B Applied Biomater 2007;81B:135-41.

Inoue S, Pereira PN, Kawamoto C, Nakajima M, Koshiro K, Tagami J, Carvalho RM, Pashley $\mathrm{DH}$, Sano $\mathrm{H}$. Effect of depth and tubule direction on ultimate tensile strength of human coronal dentin. Dent Mater J 2003;22:39-47.

International Standards Organization-ISO: DP 4049. Dental resin-based restorative materials International Standards Organization clause 1985;6-10.

Kazemi RB, Sen BH, Spangberg LS. Permeability changes of dentin treated with titanium tetrafluoride. J Dent 1999;27:531-8.

Kinney JH, Balooch M, Marshall SJ, Marshall GW Jr, Weihs TP. Hardness and Young's modulus of human peritubular and intertubular dentine. Arch Oral Biol 1996;41:9-13.

Kinney JH, Marshall SJ, Marshall GW. The mechanical properties of human dentin: a critical review and re-evaluation of the dental literature. Crit Rev Oral Biol Med 2003;14:13-29.

Kinney JH, Nalla RK, Pople JA, Breunig TM, Ritchie RO. Age-related transparent root dentin: mineral concentration, crystallite size, and mechanical properties. Biomater 2005;26:336376.

Koutsi V, Noonan RG, Horner JA, Simpson MD, Matthews WG, Pashley DH. The effect of dentin depth on the permeability and ultrastructure of primary molars. Pediatr Dent 1994;16:29-35.

Lakomaa EL, Rytömaa I. Mineral composition of enamel and dentin of primary and permanent teeth in Finland. Scand J Dent Res 1977;85:89-95.

Lanza CR, de Souza Costa CA, Furlan M, Alécio A, Hebling J. Transdentinal diffusion and cytotoxicity of self-etching adhesive systems. Cell Biol Toxicol 2009;25:533-543.

LeGeros RZ. Calcium phosphates in demineralization/ remineralization processes. J Clin Dent 1999;10:65-73.

Leventouri TH, Antonakos A, Kyriacou A, Venturelli R, Liarokapis E, Perdikatsis V. Crystal Structure Studies of Human Dental Apatite as a Function of Age. Int J Biomater 2009;1-6. 
Leventouri TH, Antonakos A, Kyriacou A, Venturelli R, Liarokapis E, Perdikatsis V. Crystal Structure Studies of Human Dental Apatite as a Function of Age. Int J Biomater 2009;1-6.

Low IM, Duraman N, Mahmood U. Mapping the structure, composition and mechanical properties of human teeth. Mater Sci Eng C 2008;28:243-247.

Lührs AK, Görmann B, Jacker-Guhr S, Geurtsen W. Repairability of dental siloranes in vitro. Dent Mater 2011;27:144-9.

Mahoney E, Holt A, Swain M, Kilpatrick N. The hardness and modulus of elasticity of primary molar teeth: an ultra-micro-indentation study. J Dent 2000;28:589-94.

Manson-Hing LR, Bloxon RM. A stepwedge quality assurance test for machine and processor in dental radiography. J Am Dent Assoc 1985;110:910-3.

Maroli S, Khera SC, Krell KV. Regional variation in permeability of young dentin. Oper Dent 1992;17:93-100.

Marshall GW Jr, Marshall SJ, Kinney JH, Balooch M. The dentin substrate: structure and properties related to bonding. J Dent 1997;25:441-58.

Mejàre I, Stenlund $\mathrm{H}$. Caries rates for the mesial surface of the first permanent molar and the distal surface of the second primary molar from 6 to 12 years of age in Sweden. Caries Res 2000;34:454-461.

Mejàre I, Stenlund $\mathrm{H}$, Julihn A, Larsson I, Permert L. Influence of approximal caries in primary molars on caries rate for the mesial surface of the first permanent molar in swedish children from 6 to 12 years of age. Caries Res 2001;35:178-85.

Menezes-Oliveira MAH. Comparação dos aspectos morfológicos e químicos de esmalte e dentina de dentes decíduos e permanentes [tese]. Ribeirão Preto: Faculdade de Odontologia de Ribeirão Preto, Universidade de São Paulo; 2009.

Miguez PA, Pereira PN, Atsawasuwan P, Yamauchi M. Collagen cross-linking and ultimate tensile strength in dentin. J Dent Res 2004;83:807-10.

Mjör IA. Dentin permeability: the basis for understanding pulp reactions and adhesive technology. Braz Dent J 2009;20:3-16. 
Nakamichi I, Iwaku M, Fusayama T. Bovine teeth as possible substitutes in the adhesion test. J Dent Res 1983;62:1076-81.

Nishitani Y, Yoshiyama M, Tay FR, Wadgaonkar B, Waller J, Agee K, Pashley DH. Tensile strength of mineralized/demineralized human normal and carious dentin. J Dent Res 2005;84:1075-8.

Nör JE, Feigal RJ, Dennison JB, Edwards CA. Dentin bonding: SEM comparison of the dentin surface in primary and permanent teeth. Pediatr Dent 1997;19:246-52.

Pashley DH, Livingston MJ. Effect of molecular size on permeability coefficients in human dentine. Arch Oral Biol 1978a;23:391-5.

Pashley DH, Livingston MJ. Regional resistences to fluid flow in human dentine in vitro. Arch Oral Biol 1978b;23:807-10.

Pashley DH, Thompson SM, Stewart FP. Dentin permeability: effects of temperature on hydraulic conductance. J Dent Res 1983;62:956-9.

Pashley D, Okabe A, Parham P. The relationship between dentin microhardness and tubule density. Endod Dent Traumatol 1985;1:176-9.

Pashley $\mathrm{DH}$, Ciucchi B, Sano $\mathrm{H}$, Horner JA. Permeability of dentin to adhesive agents. Quintessence Int 1993;24:618-31.

Pashley DH, Sano H, Ciucchi B, Yoshiyama M, Carvalho RM. Adhesion testing of dentin bonding agents: a review. Dent Mater 1995;11:117-25.

Pashley DH, Carvalho RM, Sano H, Nakajima M, Yoshiyama M, Shono Y, Fernandes CA, Tay FR. The micro-tensile bond test: A review. J Adhesive Dent 1999;1:299-309.

Pécora JD. Contribuição ao estudo de permeabilidade dentinária radicular. Apresentação de um método histoquímico e análise morfométrica [dissertação]. Ribeirão Preto: Faculdade de Odontologia de Ribeirão Preto, Universidade de São Paulo; 1985.

Roy S, Basu B. Mechanical and tribological characterization of human tooth. Mater Character 2008;59:747-756.

Ryou H, Amin N, Ross A, Eidelman N, Wang DH, Romberg E, Arola D. Contributions of microstructure and chemical composition to the mechanical properties of dentin. J Mater Sci Mater Med 2011;22:1127-35. 
Sano H, Ciucchi B, Matthews WG, Pashley DH. Tensile properties of mineralized and demineralized human and bovine dentin. J Dent Res 1994;73:1205-1211.

Schilke R, Lisson JA, Bauss O, Geurtsen W. Comparison of the number and diameter of dentinal tubules in human and bovine dentine by scanning electron microscopic investigation. Arch Oral Biol. 2000;45:355-61.

Senawongse $P$, Harnirattisai $C$, Shimada $Y$, Tagami J. Effective bond strength of current adhesive systems on deciduous and permanent dentin. Oper Dent 2004;29:196-202.

Shashikiran ND, Gunda S, Subba Reddy W. Comparison of resin-dentine interface in primary and permanent teeth for three different durations of dentine etching. J Indian Soc Pedod Prev Dent 2002;20:124-31.

Soares LES, do Espírito Santo AM, Brugnera A, Zanin FA, Martin AA. Effects of Er:YAG laser irradiation and manipulation treatments on dentin components, part 2: energy-dispersive $X$ ray fluorescence spectrometry study. J Biomed Opt 2009;14:024002.

Sønju Clasen AB, Ruyter IE. Quantitative determination of type A and type B carbonate in human deciduous and permanent enamel by means of Fourier transform infrared spectrometry. Adv Dent Res 1997;11:523-7.

Souza FCPP, Pardini LC, Cruvinel DR, Hamida HM, Garcia LF. In vitro comparison of the radiopacity of cavity lining materials with human dental structures. J Conserv Dent 2010;13:65-70.

Staninec M, Marshall GW, Hilton JF, Pashley DH, Gansky SA, Marshall SJ, Kinney JH. Ultimate tensile strength of dentin: Evidence for a damage mechanics approach to dentin failure. J Biomed Mater Res 2002;63:342-5.

Subba Reddy V, Chowdhary N. Dentin comparison in primary and permanent molars under transmitted and polarised light microscopy: an in vitro study. J Indian Soc Pedod Prev Dent 2010;28:167-72.

Sumikawa DA, Marshall GW, Gee L, Marshall SJ. Microstructure of primary tooth dentin. Pediatr Dent 1999;21:439-44.

Suzuki T, Finger WJ. Dentin adhesives: site of dentin vs. bonding of composite resins. Dent Mater 1988;4:379-83. 
Tagami J, Tao L, Pashley DH. Correlation among dentin depth, permeability, and bond strength of adhesive resins. Dent Mater 1990;6:45-50.

Tagami J, Hosoda $\mathrm{H}$, Burrow MF, Nakajima M. Effect of aging and caries on dentin permeability. Proc Finn Dent Soc 1992;88:149-54.

Tronstad L. Ultrastructural observations on human coronal dentin. Scand J Dent Res 1973;81:101-11.

Van Dijken JWV,Wing KR, Ruyter IE. An evaluation of the radiopacity of composite restorative materials used in Class I and II cavities. Acta Odontol Scandi 1989;47:401-407.

Van Noort R, Cardew GE, Howard IC, Noroozi S. The effect of local interfacial geometry on the measurement of the tensile bond strength to dentin. J Dent Res 1991;70:889-93.

Watts DC, McCabe JF. Aluminium radiopacity standards for dentistry: an international survey. J Dent 1999;27:73-8.

Wentrup-Byrne E, Armstrong CA, Armstrong RS, Collins BM. Fourier transform Raman microscopic mapping of the molecular components in a human tooth. J Raman Spectrosc 1997;28:151-8. 


\section{ANEXo A - APRovação do Comitê de Ética}

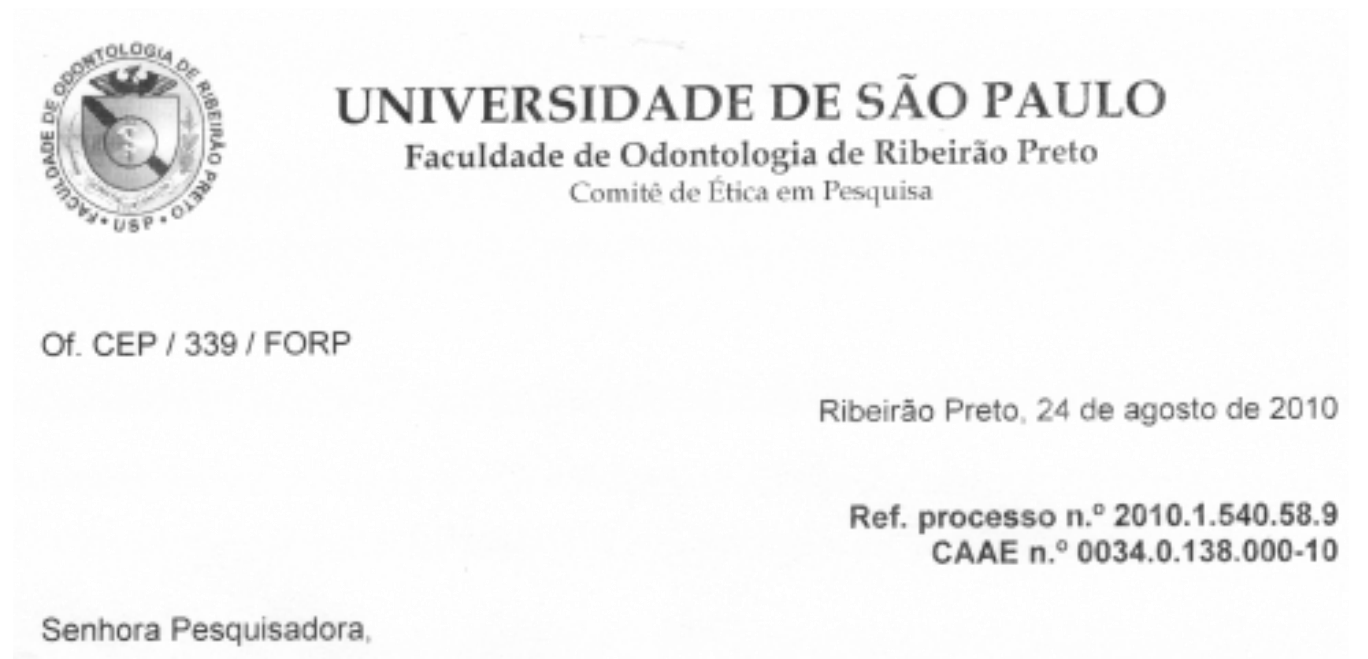

Senhora Pesquisadora

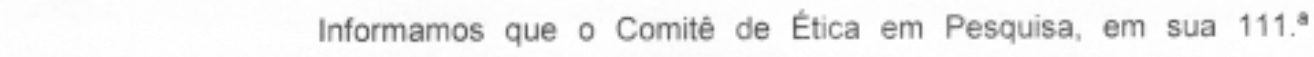
șessăo, realizada em 19/08/2010, aprovou o deservolvimento do projeto de pesquisa

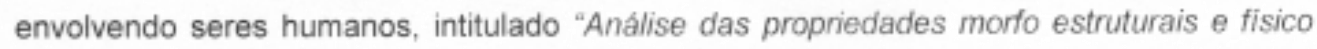
quimicas da dentina de dentes deciduos e permanentes - estudo in vitro

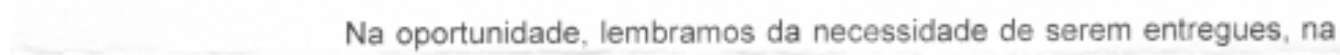
secretaria do CEP, o Relatório Parcial em 19/08/2011 e o Relatório Final em 19/08/2012, com os respectivos formulários preenchidos pelo pesquisador responsável.

Lembramos ainda que, quando da submissão dos relatórios a este

Comitê, quaisquer inclussőes ou modificaçōes no projeto original deverăo ser comuniçadas è justificadas ao CEP através do formulário supracitado
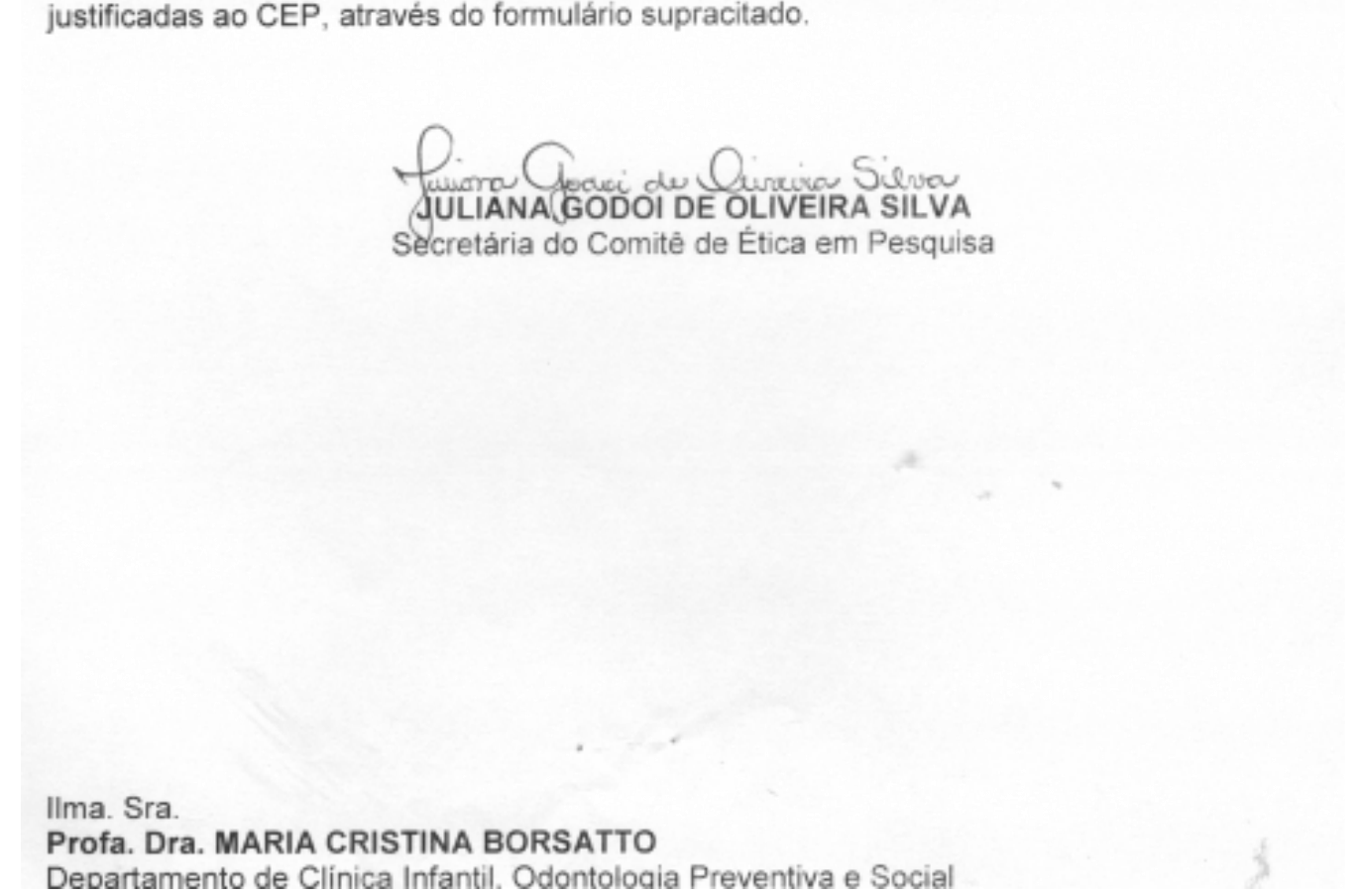

Profa. Dra. MARIA CRISTINA BORSATTO

Departamento de Clinica Infantil.. Odontologia Preventiva e Socia 